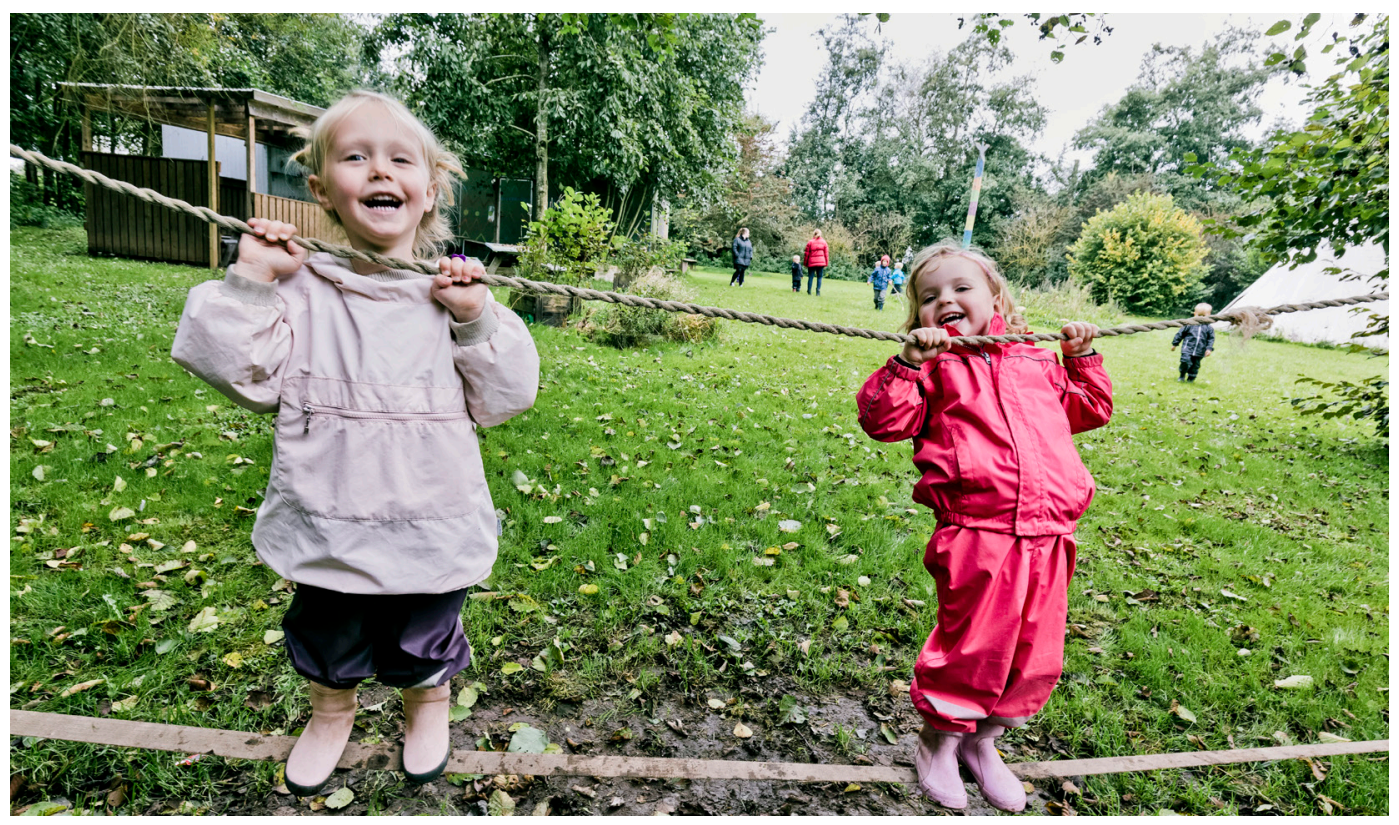

\title{
Bevægelse i dagtilbud
}

\author{
KRISTIAN FAHNØE MUNKSGAARD, THOMAS SKOVGAARD \& \\ LISBETH RUNGE LARSEN
}

På legepladsen, i motorikrummet eller på gangene i et dansk dagtilbud ${ }^{1}$ støder man helt sikkert på børn, der løber, hopper, tumler eller triller frem og tilbage og ind i mellem hinanden. Det er der mange grunde til at glædes over, og samtidig arbejde for at endnu flere får en fysisk aktiv hverdag i dagtilbud. Det er nemlig sådan, at bevægelse fremmer børns glæde (Sørensen, 2012), og bevægelse har gavnlige effekter på motorisk udvikling, psykosocial sundhed og kognition hos børn i o-6 års alderen (Sundhedsstyrelsen, 2016).

1 Ordet dagtilbud dækker i denne artikel over vuggestuer, børnehaver og integrerede institutioner på o-6 års området. 


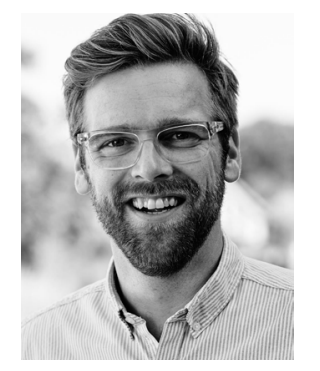

\author{
KRISTIAN FAHNØE MUNKSGAARD \\ Cand.scient.san.publ. \\ Adjunkt, University College Lillebælt \\ kfmu@ucl.dk
}

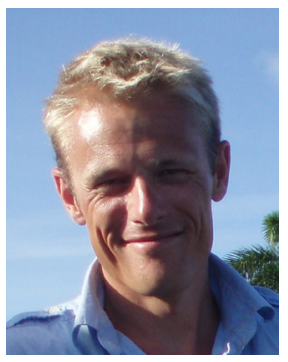

THOMAS SKOVGAARD

Ph.d.

Lektor og centerleder, Institut for Idræt og Biomekanik, SDU

tskovgaard@health.sdu.dk

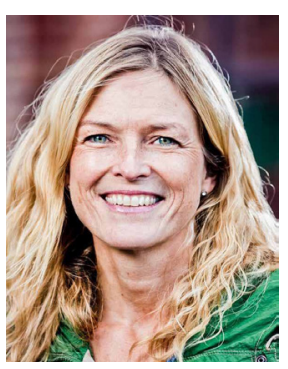

\title{
LISBETH RUNGE LARSEN
}

Ph.d.

Adjunkt og centerkoordinator, University College Lillebælt

lrla@ucl.dk

\section{INDLEDNING}

Hvor meget og med hvilken kvalitet o-6 årige børn i danske dagtilbud faktisk bevæger sig, er uvist (Sundhedsstyrelsen, 2016). International forskning indikerer, at en del børn i dagtilbud ikke bevæger sig særlig meget (Sørensen, 2012). I lande som Finland (Reunamo et al., 2014), Canada (Froehlich Chow \& Humbert, 2014), USA (Coleman \& Dyment, 2013; Howie et al., 2016), Australien (Little \& Sweller, 2015) og Norge (Giske, Tjensvoll, \& Dyrstad, 2010), hvor der er formuleret konkrete anbefalinger til mængde og intensitet for børns bevægelse i o-6 års alderen, tyder undersøgelser på, at børn ikke lever op til anbefalingerne. Yderligere ses det fx $\mathrm{i}$ et studie af 10 amerikanske dagtilbud, at næsten tre fjerdedele af børns tid i dagtilbud er stillesiddende (Tandon, Saelens, \& Christakis, 2015).

Forskning viser, at det enkelte dagtilbud har stor betydning for mængden af børns fysiske aktivitet, når de er i børnehave (Grøntved et al., 2009). Samtidig rapporterer Danmarks Evalueringsinstitut (EVA), i en landsdækkende evaluering af læreplanstemaerne foretaget via spørgeskemaer til 106 pædagogiske konsulenter og 1510 børnehaveklasseledere i landets kommuner, at "krop og bevægelse" er et 
af de læreplanstemaer, hvor børn har udviklet sig mindst ved skolestart(Danmarks Evalueringsinstitut, 2012). I en nylig undersøgelse på o-2 års-området ses, at "krop og bevægelse" som læreplanstema i dagtilbuddene ikke har samme prioritet som fx "sociale kompetencer" og "barnets alsidige og personlige udvikling" (Danmarks Evalueringsinstitut, 2016).

Der er altså god grund til at arbejde for at øge mængden og kvaliteten af børns bevægelse i danske dagtilbud samt at undersøge, hvordan bevægelse kan bruges i pædagogiske og didaktiske sammenhænge.

\section{FORMÅL}

Formålet med denne artikel er, At undersøge hvilke faktorer, der har betydning for pædagogers didaktiske arbejde med at øge børns muligheder for bevægelse.

\section{METODE}

Artiklen har form af et 'Realist Review' (Pawson, Greenhalgh, Harvey, \& Walshe, 2005). Dette er særlig relevant, da kernespørgsmålet i denne type review lyder: Hvad virker, for hvem og i hvilke sammenhænge? Via et litteraturstudie, organiseret og diskuteret i en formuleret teoretisk ramme, åbner Realist Review tilgangen i denne sammenhæng op for at søge efter de mekanismer, der kan forklare, hvordan der arbejdes med, og hvordan der kan arbejdes med at understøtte mindre børns bevægelse. Fokus er altså ikke udelukkende at rapportere sluteffekter af børns bevægelse i dagtilbud (Pawson et al., 2005).

\section{Litteraturstudie}

Litteraturstudiet baserer sig på metoder præsenteret af Wichmann-Hansen, Eika, \& Mørcke (2007). Søgninger er udført i de videnskabelige databaser: Eric, Scopus, Web Of Science, og Nordic Base of Early Childhood Education and Care (NBECEC). Der har været følgende inklusionskriterier:

- Videnskabelige studier foretaget i perioden 2006-2016.

- Videnskabelige studier foretaget på empiri indsamlet før 2006, men rapporteret i perioden 2006-2016.

- Kvalitative og kvantitative forskningsdesign.

- Studier skrevet på dansk, norsk, svensk eller engelsk.

- Studier med data indsamlet i Europa, Nordamerika eller Australien.

- Studier med data på børn i alderen o-6 år og pædagoger, der arbejder med børn i samme alder. 
- Studier, hvor bevægelse eller idræt er det centrale genstandsfelt.

- Studier omhandlende børn uden diagnoser.

Databasesøgningen til litteraturstudiet er foretaget i sidste del af 2016. Den er udført med bloksøgninger kombineret med relevante boolske termer. Tabellerne 1-4 viser søgeord og søgekombinationer i de benyttede databaser. De inkluderede studier er analyseret på baggrund af seks apriori kodede temaer. Temaerne er defineret af de seks kategorier i den didaktiske relationsmodel (Hiim \& Hippe, 2007), som udgør artiklens teoretiske ramme. Der er yderligere foretaget kædesøgninger ${ }^{2}$ i det fundne materiale. Det kvalitative analyseprogram "NVIVO 11" er anvendt i analysen.

Tabel 1: Oversigt over anvendte søgeord gennemført som bloksøgning i ERIC. Søgestrengene er kombineret med den boolske term "AND"

\begin{tabular}{|c|c|c|}
\hline Søgestreng blok 1 & Søgestreng blok 2 & Søgestreng blok 3 \\
\hline $\begin{array}{l}\text { Movement OR "Physical activity" } \\
\text { OR physical activity OR Exercise } \\
\text { OR sport OR "Motor learning" OR } \\
\text { "Body awareness" OR "Sense of } \\
\text { embodiment" OR "Body language" } \\
\text { OR “Motor activity" OR “Movement } \\
\text { theory" OR "Educational theory" } \\
\text { OR "Educational psychology" OR } \\
\text { "physical education" OR "Physical } \\
\text { litteracy" OR Didactics OR "phys- } \\
\text { ical learning" OR "child behavior" } \\
\text { OR "Physical education and } \\
\text { training" OR "play and playthings" } \\
\text { OR "physical activity programs" } \\
\text { OR "body pedagogies" OR "body } \\
\text { pedagogy" OR "body didactis" OR } \\
\text { "body learning" OR "Body knowl- } \\
\text { edge" OR "Physical education } \\
\text { program" OR Embodiment OR } \\
\text { "physical educations programs" } \\
\text { OR pedagogy }\end{array}$ & $\begin{array}{l}\text { "Day care" OR "Day care center" } \\
\text { OR Kindergarten OR Preschool } \\
\text { OR "nursery school" OR "day } \\
\text { nursery" OR infant OR Infants OR } \\
\text { "small children" OR Children OR } \\
\text { "Child care" OR "Child Day Care } \\
\text { Centers" OR "Early childhood } \\
\text { movement" OR "Early childhood } \\
\text { education" OR Toddler }\end{array}$ & $\begin{array}{l}\text { Teacher OR Kindergartenteacher } \\
\text { OR Educator OR Pedagogue OR } \\
\text { "Social educator" OR "kindergar- } \\
\text { ten employees" }\end{array}$ \\
\hline
\end{tabular}

2 "Kædesøgning består i, at man finder egnet litteratur ved, at den ene tekst fører til den næste, som fører til den næste igen osv. Kædesøgningen har sin styrke i at føre fra en god reference til en anden, og ved at man gennem litteratursøgningen kan følge argumenternes udvikling”(Jørgensen \& Rienecker, 2014). 
Tabel 2: Oversigt over anvendte søgeord gennemført som bloksøgning i SCOPUS. Søgestrengene er kombineret med den boolske term "AND"

\begin{tabular}{|c|c|c|}
\hline Søgestreng blok 1 & Søgestreng blok 2 & Søgestreng blok 3 \\
\hline $\begin{array}{l}\text { Movement OR "Physical ac- } \\
\text { tivity" OR physical activity OR } \\
\text { Exercise OR sport OR "Motor } \\
\text { learning" OR "Body awareness" } \\
\text { OR "Sense of embodiment" OR } \\
\text { "Body language" OR "Motor } \\
\text { activity" OR "Movement theory" } \\
\text { OR “Educational theory" OR } \\
\text { "Educational psychology" OR } \\
\text { "physical education" OR "Physical } \\
\text { litteracy" OR Didactics OR "phys- } \\
\text { ical learning" OR "child behavior" } \\
\text { OR “Physical education and } \\
\text { training" OR "play and playthings" } \\
\text { OR "physical activity programs" } \\
\text { OR "body pedagogies" OR "body } \\
\text { pedagogy" OR "body didactis" OR } \\
\text { "body learning" OR “Body knowl- } \\
\text { edge" OR "Physical education } \\
\text { program" OR Embodiment OR } \\
\text { "physical educations programs" } \\
\text { OR pedagogy }\end{array}$ & $\begin{array}{l}\text { "Day care" OR "Day care center" } \\
\text { OR Kindergarten OR Preschool } \\
\text { OR "nursery school" OR "day } \\
\text { nursery" OR infant OR Infants OR } \\
\text { "small children" OR Children OR } \\
\text { "Child care" OR "Child Day Care } \\
\text { Centers" OR "Early childhood } \\
\text { movement" OR "Early childhood } \\
\text { education" OR Toddler }\end{array}$ & $\begin{array}{l}\text { Teacher OR Kindergartenteacher } \\
\text { OR Educator OR Pedagogue OR } \\
\text { "Social educator" OR "kindergar- } \\
\text { ten employees" }\end{array}$ \\
\hline
\end{tabular}


Tabel 3: Oversigt over anvendte søgeord gennemført som bloksøgning i Web of Science. Søgestrengene 1-3 er kombineret med den boolske term "AND" hvorefter resultatet er kombineret med søgestreng 4 vha. den boolske term "NOT"

\begin{tabular}{|c|c|c|c|}
\hline Søgestreng blok 1 & Søgestreng blok 2 & Søgestreng blok 3 & Søgestreng blok 4 \\
\hline $\begin{array}{l}\text { Movement OR “Physical } \\
\text { activity" OR physical } \\
\text { activity OR Exercise } \\
\text { OR sport OR "Motor } \\
\text { learning" OR "Body } \\
\text { awareness" OR "Sense } \\
\text { of embodiment" OR } \\
\text { "Body language" OR } \\
\text { "Motor activity" OR } \\
\text { "Movement theory" OR } \\
\text { "Educational theory" } \\
\text { OR "Educational psy- } \\
\text { chology" OR "physical } \\
\text { education" OR “Physical } \\
\text { litteracy" OR Didactics } \\
\text { OR "physical learning" } \\
\text { OR "child behavior" OR } \\
\text { "Physical education and } \\
\text { training" OR "play and } \\
\text { playthings" OR "physical } \\
\text { activity programs" OR } \\
\text { "body pedagogies" } \\
\text { OR "body pedagogy" } \\
\text { OR "body didactis" } \\
\text { OR "body learning" } \\
\text { OR "Body knowledge" } \\
\text { OR "Physical edu- } \\
\text { cation program" OR } \\
\text { Embodiment OR } \\
\text { "physical educations } \\
\text { programs" OR pedagogy }\end{array}$ & $\begin{array}{l}\text { "Day care" OR "Day care } \\
\text { center" OR Kindergarten } \\
\text { OR Preschool OR } \\
\text { "nursery school" OR } \\
\text { "day nursery" OR } \\
\text { infant OR Infants OR } \\
\text { "small children" OR } \\
\text { Children OR "Child care" } \\
\text { OR "Child Day Care } \\
\text { Centers" OR "Early } \\
\text { childhood movement" } \\
\text { OR "Early childhood } \\
\text { education" OR Toddler }\end{array}$ & $\begin{array}{l}\text { Teacher OR } \\
\text { Kindergartenteacher } \\
\text { OR Educator OR } \\
\text { Pedagogue OR "Social } \\
\text { educator" OR "kinder- } \\
\text { garten employees" }\end{array}$ & $\begin{array}{l}\text { "primary school" OR } \\
\text { adolescent OR adoles- } \\
\text { cents OR autistic OR } \\
\text { ADHD OR "Attention } \\
\text { Deficit Hyperactivity } \\
\text { Disorder" OR "Primary } \\
\text { education" OR } \\
\text { "Elementary school" }\end{array}$ \\
\hline
\end{tabular}

\section{Tabel 4: Oversigt over anvendte søgeord gennemført som enkeltordssøgninger i NB-ECEC}




\section{Teoretisk ramme}

I artiklen anvendes den didaktiske relationsmodel (herefter "relationsmodellen") (Hiim \& Hippe, 2007) som teoretisk ramme. Relationsmodellen har et generelt didaktisk sigte og præsenterer seks kategorier, der alle er indbyrdes afhængige i planlægningen af didaktiske processer. Modellen ses i figur 1.

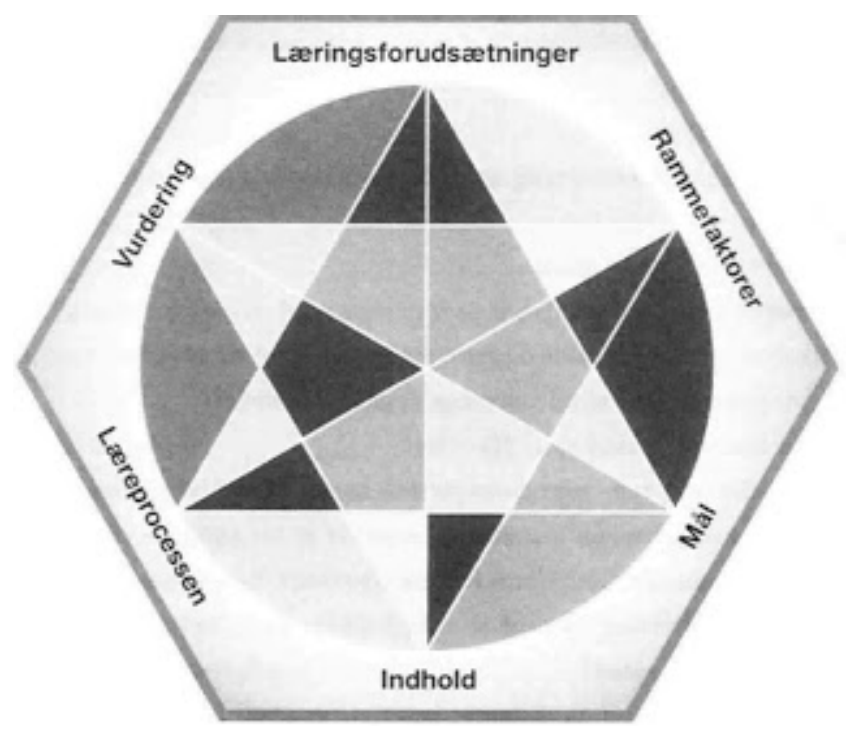

Figur 1: Den didaktiske relationsmodel (Hiim og Hippe, 2007)

Styrken ved modellen er, at den tager udgangspunkt i relationelle og kontekstuelle sammenhænge, som er karakteristisk for pædagogisk praksis, undervisning og læring (Hiim \& Hippe, 2007). Relationsmodellen bruges til at sætte resultaterne fra artiklens litteraturstudie i sammenhæng med pædagogens didaktiske handlemuligheder. Dens funktion er dermed at sætte fokus på pædagogens praksis og pædagogiske aktiviteter med børn og bevægelse i dagtilbud. I artiklen sidestilles ordene "pædagogisk praksis" og "børn" med Hiim og Hippes termer "undervisning" og "elever" i deres beskrivelser af relationsmodellen. Nærværende artikels didaktiske fundament bygger på Klafkis kritisk konstruktive didaktik og dennes demokratiske idealer og visioner (Klafki, 2011). Det betyder, at didaktikkens opgave er at forholde sig reflekteret, undersøgende og problematiserende til den pædagogiske bevægelsespraksis i dagtilbud. Det er hensigten at fremme et diskuterende forhold mellem didaktisk teori, forskningsbaseret viden og bevægelsespædagogisk praksis. 


\section{RESULTATER}

Indledningsvist er der identificeret 3.650 studier. På baggrund af artiklens inklusionskriterier er der inkluderet 28 studier og via kædesøgninger 12 studier. I alt 40 studier er taget med i litteraturstudiet. Resultater og screening af fundne studier er opstillet i tabel 5. Tabel 6 viser antallet af inkluderede studier i artiklens diskussionsafsnit fordelt på relationsmodellens kategorier og anvendt undersøgelsesmetode. I bilag 1 ses tabel 7, der viser en oversigt over alle inkluderede studier med udvalgte karakteristika.

Tabel 5: Resultater og screening af den fundne litteratur

\begin{tabular}{|l|l|l|}
\hline Screening & Inklusionsgrund/eksklusionsgrund & Antal udgivelser \\
\hline $\begin{array}{l}\text { Identificerede studier ved søgning } \\
\text { i Scopus, Web of Science (WOS), } \\
\text { ERIC og NB-ECEC }\end{array}$ & $\begin{array}{l}\text { Søgeord og kombinationer kan ses i tabel } \\
1-4 .\end{array}$ & Scopus: 943 \\
\hline $\begin{array}{l}\text { Udvalgte studier efter gennemgang } \\
\text { af overskrifter }\end{array}$ & $\begin{array}{l}\text { Ved disse gennemlæsninger er der fore- } \\
\text { taget vurdering på baggrund af artiklens } \\
\text { inklusions- kriterier. }\end{array}$ & ERIC: 1448 \\
\hline $\begin{array}{l}\text { Udvalgte studier efter læsning af } \\
\text { abstracts }\end{array}$ & & NB-ECEC: 34 \\
\hline $\begin{array}{l}\text { Inkluderede studier efter læsning af } \\
\text { "full text" }\end{array}$ & & 341 \\
\hline $\begin{array}{l}\text { Inkluderede studier på baggrund af } \\
\text { kædesøgning }\end{array}$ & $\begin{array}{l}\text { Studier identificeret via kædesøgning i "in- } \\
\text { kluderede studier efter læsning af "full text" }\end{array}$ & 11850 \\
\hline \begin{tabular}{l} 
Antal studier inkluderet $i$ alt \\
\hline
\end{tabular} & & 28 \\
\hline
\end{tabular}


Tabel 6: Antal studier i artiklens diskussionsafsnit fordelt på kategori i den didaktiske relationsmodel og anvendt undersøgelsesmetode (nogle studier anvendes i flere af artiklens diskussionsafsnit).

\begin{tabular}{|l|c|c|c|c|}
\hline $\begin{array}{l}\text { Kategori i den didaktiske } \\
\text { relationsmodel }\end{array}$ & $\begin{array}{c}\text { Kvalitativ } \\
\text { metode }\end{array}$ & $\begin{array}{c}\text { Kvantitativ } \\
\text { metode }\end{array}$ & $\begin{array}{c}\text { Mixed } \\
\text { Methods }\end{array}$ & I alt \\
\hline Læringsforudsætninger & 3 & 2 & 1 & 6 \\
\hline $\begin{array}{l}\text { Rammefaktorer: Pædagogen som } \\
\text { rollemodel }\end{array}$ & 8 & 4 & 0 & 12 \\
\hline $\begin{array}{l}\text { Rammefaktorer: Læringsmiljets } \\
\text { fysiske udformning og fremtræden }\end{array}$ & 7 & 9 & 2 & 18 \\
\hline $\begin{array}{l}\text { Rammefaktorer: Politikker, strategier } \\
\text { og uddannelse }\end{array}$ & 5 & 6 & 1 & 12 \\
\hline Indhold og Læreproces & 3 & 10 & 2 & 15 \\
\hline Mål og vurdering & 1 & 2 & 1 & 4 \\
\hline
\end{tabular}

\section{DISKUSSION}

Med udgangspunkt i relationsmodellen diskuteres resultaterne og deres betydning for, hvordan pædagoger i dagtilbud kan anvende bevægelse som didaktisk metode.

\section{LAERINGSFORUDSATNINGER}

I dette afsnit diskuteres hvilke faktorer, der har betydning for børns læringsforudsætninger og hvorledes disse faktorer påvirker de didaktiske valg, pædagoger kan tage, når der arbejdes med børn og bevægelse.

Børns læringsforudsætninger beskrives som ”De psykiske, fysiske, sociale og faglige muligheder og problemer, eleven har på forskellige områder i forhold til den aktuelle undervisning" (Hiim \& Hippe, 2007). I en dagtilbudskontekst bidrager alle børn til det læringsrum, som er til stede i den pædagogiske praksis. Pædagogen må tage højde for børnenes sociale og kulturelle baggrund, kundskaber, færdigheder, holdninger, fysiske og psykiske formåen samt hjemmets sociale og økonomiske forhold (Hiim \& Hippe, 2007).

Børns læringsforudsætninger er blandt andet påvirkelige via indflydelse fra forældre og pædagoger (Froehlich Chow \& Humbert, 2014). Interessant er det, at nogen forskning viser, at interventioner rettet mod at øge mængden af børns bevægelse har en større virkning, når den sker i dagtilbud og er ledet af pædagoger, fremfor i hjemmet under ledelse af forældre (Gordon, Tucker, Burke, \& Carron, 2013). I denne sammenhæng viser forskning, at barrierer for børns bevægelse kan være, 
at børn ikke har egnet tøj med til udeaktivitet, at forældre ikke viser opbakning til bevægelsesaktiviteter i dagtilbud (Froehlich Chow \& Humbert, 2014), svær adgang til bevægelsesområder, store distancer til idrætsklubber, forældres økonomi og begrænsede muligheder for transport til idrætsaktiviteter (De Craemer et al., 2013). Omvendt viser det sig, at forældre, der er involveret i aktiviteter i dagtilbuddet er mere tilbøjelige til at sørge for korrekt påklædning til børn, og forældre med positiv opfattelse af bevægelse kan influere andre forældre i samme retning (Froehlich Chow \& Humbert, 2014). Det kunne pege på, at der er potentiale i at inddrage forældre for at øge mængden af børns bevægelse. I relation til børns læringsforudsætninger ses det yderligere, at køn har en betydning for barnets mængde af fysisk aktivitet. Drenge er mere fysisk aktive end piger (Olesen, Kristensen, Korsholm, \& Froberg, 2013; Pape et al., 2016), og drenge engagerer sig oftere end piger i vilde lege med fysisk aktivitet af høj intensitet (Logue \& Harvey, 2009).

Opsummerende viser de identificerede studier, at pædagoger kan påvirke børnenes læringsforudsætninger ved aktivt at inddrage forældre i arbejdet med bevægelse i dagtilbuddet og ved at opfordre forældre til at bevæge sig med børnene i fritiden. Pædagoger må yderligere tage børnenes køn i betragtning, da drenge typisk er mere fysisk aktive end piger.

\section{RAMMEFAKTORER}

I dette afsnit diskuteres hvilke forhold, der har indflydelse på rammefaktorer og hvorledes disse påvirker de didaktiske valg, pædagoger kan tage, når der arbejdes med børn og bevægelse?

Rammefaktorer beskrives som: "... forhold, som kan fremme eller hæmme undervisning og læring på forskellige måder” (Hiim \& Hippe, 2007). Lovgivning, læreplaner, timefordeling, regelsystemer, love og cirkulærer, samarbejdsforhold blandt pædagoger, lokalmiljøet, udstyr, fysiske rammer og økonomiske rammer kan alle ses som rammefaktorer (Hiim \& Hippe, 2007). I afsnittet fokuseres på: "Pædagogen som rollemodel", "læringsmiljøets fysiske udformning", samt "politikker, strategier og uddannelse".

\section{Predagogen som rollemodel}

En rollemodel kan opfattes som en person, der tjener som eksempel og efterlignes af andre. I denne sammenhæng er pædagogens holdninger, handlinger, kundskaber, viden, kompetencer, færdigheder, kropslige fremtræden og engagement i bevægelse eksempler på relevante parametre. Derfor kan pædagogen forstås som rollemodel og rammefaktor. I Merleau Ponty's kropsfænomenologiske filosofi argumenteres der for, at pædagogen deler og skaber kropslige oplevelser sammen med barnet og har et medansvar for barnets kropslige udfoldelse og udvikling (Jo- 
hansson \& Løkken, 2014). Pædagoger kan således fremme eller hæmme læring og udvikling hos barnet gennem kropslige oplevelser og bevægelse. Forskning viser, at positive holdninger til bevægelse, kreativitet i anvendelse af bevægelse og engagement $\mathrm{i}$ bevægelse hos professionelle, er vigtige parametre, hvis børns og unges muligheder for fysisk aktivitet skal forbedres (Copeland, Kendeigh, Saelens, Kalkwarf, \& Sherman, 2012). Samtidig tyder det på, at pædagogers viden om fysisk aktivitet og bevægelse kan have betydning for mængden af børns fysiske aktivitet (Little \& Sweller, 2015). Pædagoger, der er uddannede i at anvende bevægelse i dagtilbud, rapporterer, måske ikke overraskende, at de i højere grad end pædagoger uden uddannelse, føler sig rustede og parate til at tage fat i området (Sevimli-Celik \& Johnson, 2013). Desuden har studier vist, at pædagogers personlige bevægelseserfaringer har betydning for, hvorvidt de bruger bevægelse i professionelle sammenhænge (Sevimli-Celik \& Johnson, 2013; van Zandvoort, Tucker, Irwin, \& Burke, 2010). Det fund underbygges af andre studier, der understreger, at pædagogers holdninger til børnehavebørns fysiske aktivitet har en stærk indflydelse på pædagogens professionelle praksis (Pisha, 2012). Samtidig observerer pædagoger, at en stillesiddende adfærd fra kolleger kan have en afsmittende effekt på børn (Copeland et al., 2012; Froehlich Chow \& Humbert, 2014). Anden forskning viser, at pædagoger mener, at børn er mere aktive, når pædagoger selv er aktive (De Craemer et al., 2013). Et studie af ca. 100 amerikanske pædagoger viser, at vilde lege med høj fysisk intensitet (rough n' tumble play), er de lege, der oftest stoppes af pædagoger (Logue \& Harvey, 2009) og pædagogen betegnes i et systematisk review ligefrem som en "gatekeeper to the playground" (Copeland et al., 2012). Det pointeres, at aktiv involvering og engagement fra pædagogers side er vigtige faktorer for at øge børns fysiske aktivitet, men også at der er brug for mere forskning for at dokumentere den mulige sammenhæng yderligere (Tonge, Jones, \& Okely, 2016). I modsætning til ovenstående fund finder Olesen m. fl. i en tværsnitsundersøgelse af 43 børnehaver i Odense ingen direkte sammenhæng mellem børns bevægelsesmængde og pædagogens adfærd som rollemodel (2013).

Opsummerende viser forskningen, med undtagelse af et enkelt dansk studie, at pædagogens egen interesse, involvering og engagement i bevægelse, viden om bevægelse, personlig bevægelsespraksis og den måde pædagogen fremstår aktiv eller inaktiv har en markant betydning for børns bevægelsespraksis.

\section{Læringsmiljøets fysiske udformning}

I et systematisk review rapporteres det, at tilstedeværelsen af udendørsmiljøer og større legepladser ved dagtilbuddet hænger sammen med øget fysisk aktivitet hos børn (Tonge et al., 2016). Der ses også en sammenhæng mellem store åbne pladser og øget fysisk aktivitet hos børn (Berg, 2015; Nicaise, Kahan, \& Sallis, 2011). Det at have adgang til udstyr, der stimulerer til bevægelse, rapporteres at være af 
betydning for mængden af fysisk aktivitet og for antallet af børn, der bevæger sig i løbet af dagen (De Craemer et al., 2013; Dowda et al., 2009; van Zandvoort et al., 2010). Ligeså viser et interventionsstudie fra 2008, at tilføjelse af nyt udstyr på legepladsen på kort sigt bliver efterfulgt af mindre stillesiddende aktivitet hos børn på legepladsen. Der rapporteres ikke noget om langtidseffekterne (Hannon \& Brown, 2008). Den type fund underbygges af en metaanalyse, der har undersøgt effekten af interventioner, som skal forøge børns bevægelsesmængde og intensitet. Metaanalysen viser, at interventioner, der tilføjer udstyr, har en større effekt, end interventioner uden tilføjelse af udstyr (Gordon et al., 2013). I et casestudie fremhæves pædagogens rolle som vigtig for at sikre og fastholde småbørns fysiske aktivitet og udnyttelse af de fysiske rammer i det pædagogiske arbejde (Musatti \& Mayer, 2011). Muligheden for differentieret anvendelse af legepladsudstyr er vigtig for at inspirere børn til bevægelse. Naturlige miljøer som fx skov og strand kan fordre til forskellige former for bevægelse og kan derfor motivere børn til bevægelse (Bjørgen, 2016). Yderligere har et studie fundet, at udendørs leg giver anledning til mere bevægelse med højere intensitet, end indendørs leg (Gordon et al., 2013). Samtidig ses det, at for varmt eller for koldt vejr af pædagoger opfattes som barrierer for at komme udenfor og bevæge sig (Froehlich Chow \& Humbert, 2014; Sevimli-Celik \& Johnson, 2013; van Zandvoort et al., 2010), og at regnvejrsdage har en negativ sammenhæng med mængden af børnehavebørns fysiske aktivitet (Olesen et al., 2013). Yderligere opleves det af pædagoger, at barn/voksen-ratioen

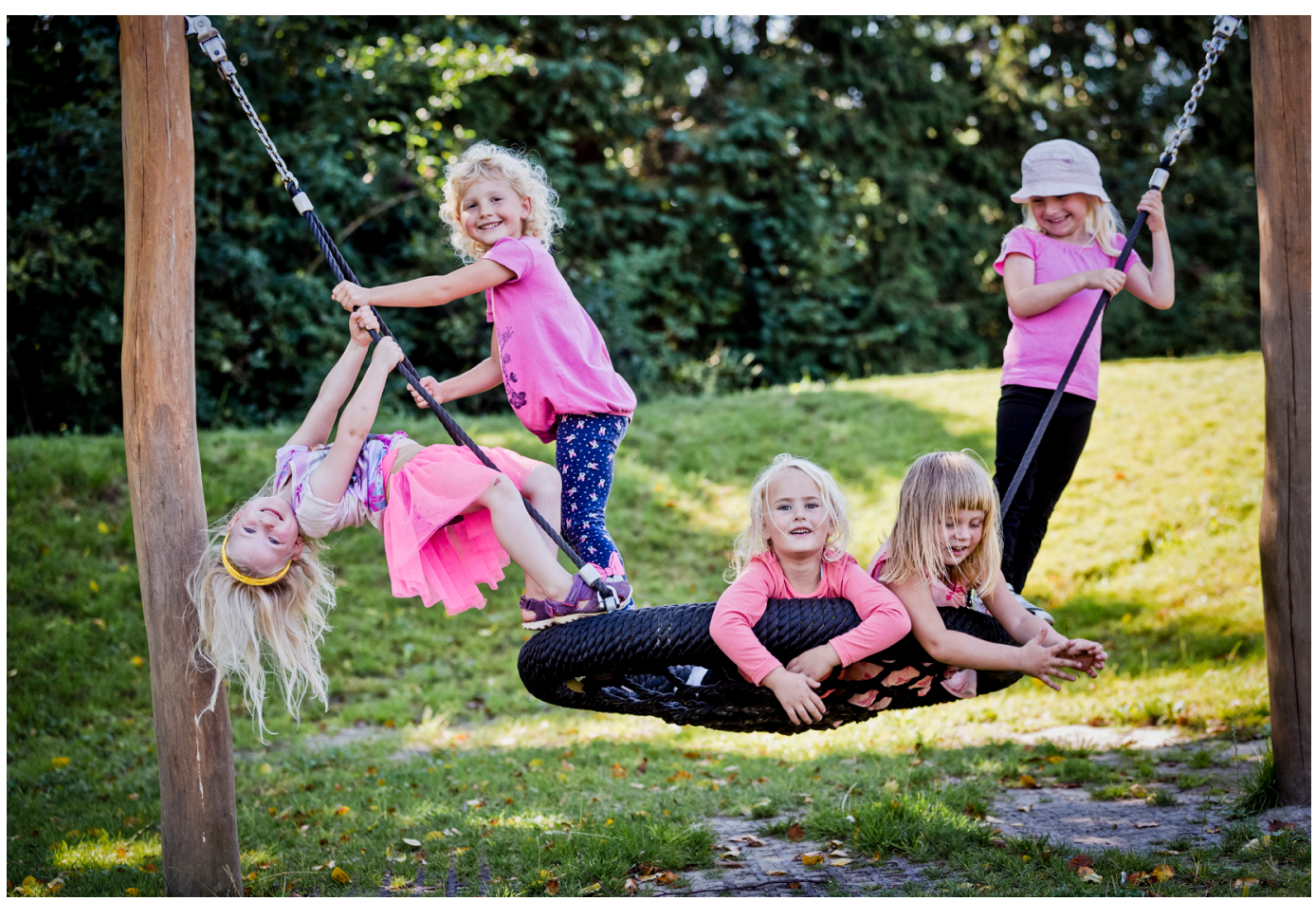


har betydning, når de skal gennemføre pædagogiske aktiviteter udendørs (Coleman \& Dyment, 2013).

Indendørsmiljøet har også betydning for mængden af fysisk aktivitet hos børn. At have et tilstrækkeligt stort område designet til bevægelse i dagtilbuddet virker positivt på mængden af børns bevægelse (Olesen et al., 2013; Sugiyama, Okely, Masters, \& Moore, 2012). Desuden viser en undersøgelse, at det er vigtigt, at pædagoger også overvejer indendørsrummenes indretning og benyttelse i planlægningen af pædagogiske aktiviteter (Archer \& Siraj, 2015). I dansk sammenhæng har det vist sig, at langt de fleste dagtilbud har adgang til udendørsfaciliteter, mens adgang til indendørsfaciliteter med plads til bevægelse er mere begrænset (Lissau, Hesse, Juhl, \& Davidsen, 2006). Pædagoger finder det nødvendigt at have adgang til varierede og opdaterede faciliteter og udstyr for at kunne gennemføre bevægelsesaktiviteter i dagtilbud. Det motiverer både børn og pædagoger (Tsangaridou, 2016).

Læringsmiljøets fysiske udformning har betydning for pædagogens didaktiske valg på en række områder. Opsummerende tyder det på, at udendørs leg giver anledning til mere bevægelse med højere intensitet end indendørsleg. Udendørsarealers størrelse og fysiske udformning af bevægelsesmiljøet har betydning for mængden af børns bevægelse i dagtilbud. Yderligere tyder det på, at det pædagogiske personale har en særlig udfordring med dårligt vejr, og når barn/voksen ratioen er for stor.

\section{Politikker, strategier og uddannelse}

Konkrete politikker og strategier for børn, bevægelse og fysisk aktivitet i dagtilbud kan bidrage til, at forældre og pædagoger lettere kan begrunde og vurdere mængden af bevægelsesaktiviteter (De Craemer et al., 2013). Nedfældede politikker om bevægelse og fysisk aktivitet øger børns daglige fysiske aktivitetsniveau og opnåelse af anbefalinger på området (Tonge et al., 2016). Pædagoger og forældre vurderer typisk mængden af børns fysiske aktivitet højere, end den i virkeligheden er (Brown et al., 2009; De Craemer et al., 2013; Little \& Sweller, 2015), og pædagogers vurdering af mængden af børns fysiske aktivitet kan indirekte have betydning for, hvor meget børn rent faktisk bevæger sig. Pædagoger, der vurderer, at børn bevæger sig tilstrækkeligt, har mindre fokus på, at børn skal bevæge sig yderligere (Coleman \& Dyment, 2013). Det rapporteres, at børn i dagtilbud, hvor personalet ikke er bekendt med anbefalingerne til fysisk aktivitet, bevæger sig mindre, end børn i børnehaver hvor personalet kender anbefalingerne (Bower et al., 2008). I en dansk sammenhæng kan det have betydning, da der ikke findes konkrete anbefalinger for, hvor meget og med hvilken intensitet børn i alderen o-4 år bør bevæge sig (Sundhedsstyrelsen, 2016). For børn i 5-6 års alderen anbefales 60 min. fysisk aktivitet om dagen ved moderat til høj intensitet (Sundhedsstyrelsen, 2016). Pæ- 
dagoger fra lande med konkrete retningslinjer for bevægelse på o-4 års området giver i vid udstrækning udtryk for, at det er vigtigt, at børn bevæger sig 60 minutter om dagen, at det er et ansvar, som dagtilbuddet skal være med til at løfte, og at pædagoger bør være uddannede til at varetage arbejdet med bevægelse (Sevimli-Celik \& Johnson, 2013; van Zandvoort et al., 2010). Coleman og Dyment (2013) pointerer, at pædagoger mener, at de har et ansvar for at bekæmpe børnefedme gennem fysisk aktivitet, og at bevægelse styrker børns fysiske, mentale og sundhedsmæssige udvikling. Desværre oplever nogle pædagoger, at de ikke er rustet til at gennemføre bevægelsesaktiviteter med børn i dagtilbud (Little \& Sweller, 2015), og at de mangler uddannelse på området (Coleman \& Dyment, 2013; Sevimli-Celik \& Johnson, 2013; Sørensen, 2012; Tsangaridou, 2016). I relation til pædagogers uddannelse viser det sig, at et øget fokus på implementering, når pædagoger tager videreuddannelse på bevægelsesområdet, giver et større udbytte af videreuddannelsen (Elliot \& Campbell, 2015), og at implementering fremmes, hvis videreuddannelse sker i det miljø, hvori pædagoger arbejder (Howie et al., 2014).

Opsummerende peger resultaterne på, at udformning af politikker og strategier og pædagogers uddannelsesniveau er vigtig for påvirkning af mængden af børns bevægelse i dagtilbud. Pædagoger bør have særlig opmærksomhed på, hvor meget det enkelte barn faktisk bevæger sig. Pædagoger angiver, at dagtilbuddene har en opgave i at tage ansvar for børns bevægelse. Der er tegn på, at en af barriererne for børns bevægelse er manglende uddannelse hos pædagogerne.

\section{INDHOLD OG LAEREPROCES}

Indhold og læreproces er tæt forbundet i den forskning, der indgår i denne artikel. Derfor kobles faktorerne, og der diskuteres hvilke faktorer, der har betydning for indhold og læreproces i pædagogiske aktiviteter og hvorledes disse påvirker de didaktiske valg, pædagoger kan tage, når der arbejdes med børn og bevægelse?

Indholdskategorien er der, hvor pædagogen udtrykker, hvad den pædagogiske praksis drejer sig om (Hiim \& Hippe, 2007) (fx hoppe, hinke lege, boldspil, dans mv.). Læreprocessen handler om de metoder og processer, som pædagogen og børnene vælger at bruge, for at børnene kan opnå læring og udvikling. Relationsmodellen betragter læring ud fra et kritisk, humanistisk udgangspunkt. Det betyder, at læring anses for at være en kreativ læreproces, som indebærer både følelsesmæssige og intellektuelle sider (Hiim \& Hippe, 2007).

\section{Læreprocesser i fri leg eller styrede aktiviteter}

Et amerikansk observationsstudie foretaget over fem måneder i to dagtilbud på 41 børn i alderen 16-36 måneder rapporterer, at børn der er overladt til indendørs fri leg, hovedsageligt vælger stillesiddende aktiviteter. Faktisk hele $74 \%$ af den obser- 
verede tid (Fees, Fischer, Haar, \& Crowe, 2015). Fysiske omgivelser, der fordrer social interaktion mellem børn, hæver intensiteten og omfanget af børns bevægelse. Social interaktion forstås som invitationer til leg, positiv respons fra andre børn, imitationer og fælles bevægelsesglæde. Pædagogen bør derfor være en katalysator for at skabe sociale interaktioner og bevægelseslege (Bjørgen, 2016). Lignende forhold ses i et mindre observationsstudie i ét dagtilbud i USA, hvor det pointeres, at udendørs leg, hvor børn kan udfordre og inspirere hinanden, kan udvikle børns fysiske, sproglige og forhandlingsmæssige kompetencer (Perry \& Branum, 2009). Dette perspektiv underbygges af studier, der rapporterer, at kvaliteten af de aktiviteter der foregår, har stor betydning for børns bevægelse (Tonge et al., 2016), samt at pædagoginitierede aktiviteter er med til at øge børns fysiske aktivitetsniveau (Brown, Googe, McIver, \& Rathel, 2009; Williams, Carter, Kibbe, \& Dennison, 2009). Tilsvarende fund ses i et randomiseret kontrolleret studie, der rapporterer, at interventioner, der kvalificerer pædagoger til at give børn flere bevægelsesmuligheder, øger mængden af bevægelse hos børn (Pate et al., 2016). I modsætning hertil observeres det $\mathrm{i}$ et finsk studie af 823 et til syv-årige børn i vuggestue og børnehave, at udendørs fri leg er kilden til hele $57 \%$ af børnenes høj-intense fysiske aktivitet (Reunamo et al., 2014). Et tværsnitsstudie af 35 belgiske dagtilbud rapporterer, at planlagte bevægelsesaktiviteter ikke bidrager væsentligt til børns mængde af moderat og hård fysisk aktivitet. Årsagerne til dette rapporteres dog at være strukturen for gennemførelse af aktiviteterne, hvor der bruges for meget tid på at forklare regler og rammer for bevægelse, hvorfor børnene er stillesiddende (Van Cauwenberghe, Labarque, Gubbels, De Bourdeaudhuij, \& Cardon, 2012). Et andet Belgisk studie viser, at hvis der inkluderes pædagogstyrede bevægelsesakti-

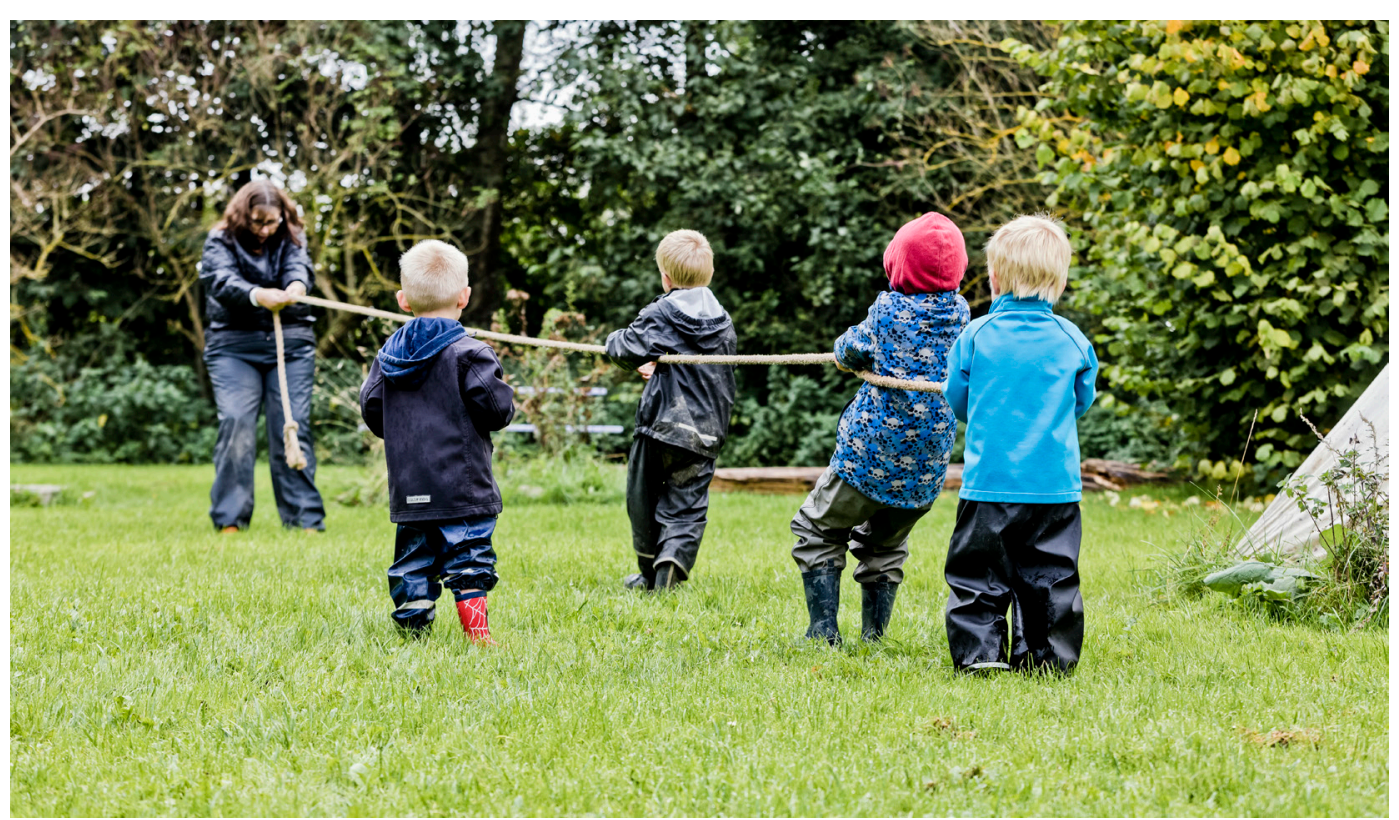


viteter i løbet af dagen i dagtilbud, højnes mængden af børns bevægelse og mængden af børns bevægelse udenfor dagtilbuddet falder ikke (Van Cauwenberghe, De Craemer, De Decker, De Bourdeaudhuij, \& Cardon, 2013). Emnet er også taget op af Canadiske forskere, der på baggrund af fokusgruppeinterview med 54 pædagoger pointerer, at der er brug for både fri leg og struktureret pædagogisk aktivitet, for at alle børn i dagtilbud bevæger sig nok ${ }^{3}$ (van Zandvoort et al., 2010). Et dansk studie opstiller fem faktorer i den pædagogiske praksis, der har særlig betydning for at børn er fysisk aktive; 1) Hvor ofte og hvilke strukturerede krops- og bevægelsesaktiviteter, der organiseres for børn, 2) Hvorvidt pædagoger tager ansvar for, at børn er parate til bevægelse, 3) At pædagoger stiller krav i forhold til børns deltagelse i bevægelse, 4) Hvilke muligheder der er for, at børn kan være fysisk aktive i selvvalgte lege, både indendørs og udendørs og 5) Hvilke muligheder børn har for at engagere sig i risikolege (Sørensen, 2012).

\section{Særlige indholdsområder}

Forskningen viser, at forskellige indholdsområder er særligt gavnlige for bevægelse. Canadiske forskere har fremhævet musik som en særlig god stimulator til at skabe bevægelse hos børn i dagtilbud (van Zandvoort et al., 2010). I et studie af 149 amerikanske pædagogers holdninger til børns fysiske aktivitet rapporteres boldlege, løb, cykling, klatring, forhindringsbane, lege med regler, at hoppe og naturvandring som de mest velegnede udendørsaktiviteter, for at få børn til at bevæge sig (Sevimli-Celik \& Johnson, 2013). Et andet studie viser, at de mest almindelige aktiviteter i udendørs leg, som stimulerer til "ikke-stillesidende aktivitet”, er brugen af bolde og objekter, åbne pladser, legetøj med hjul, fast monteret udstyr på legepladsen, socio-dramatiske rekvisitter, pædagogarrangerede bevægelsesaktiviteter og flytbart udstyr (Brown et al., 2009). Brugen af forhindringer i børns bevægelsesaktiviteter ser ud til at højne mængden af moderat og hård fysisk aktivitet, hvorimod brugen af kastegenstande ser ud til at mindske mængden af moderat og hård fysisk aktivitet (Van Cauwenberghe et al., 2012). Udviklingen af konkrete aktiviteter bør ske i det miljø, hvor børn og pædagoger befinder sig. Det øger implementeringsgraden (Howie et al., 2014; Howie et al., 2016).

Opsummerende tyder noget forskning på, at pædagogstyrede aktiviteter højner børns mængde af bevægelse, mens anden forskning fx viser, at udendørs fri leg er kilde til en stor del af børns bevægelse, og at pædagogstyrede aktiviteter ikke altid medfører øget bevægelse. Der er altså ikke entydig retning i forskningen vedrørende betydningen af fri leg eller struktureret aktivitet, hvorfor både pædagogstyrede aktiviteter og fri leg bør prioriteres.

3 At bevæge sig nok, betyder i dette studie to timer dagligt ifølge guidelines fra Ontario Ministry of Child \& Youth Services 1990, Canada. 


\section{MÅL OG VURDERING}

I dette afsnit diskuteres hvilke forhold, der har indflydelse på kategorierne mål og vurdering i relationsmodellen, og hvorledes disse påvirker de didaktiske valg, pædagoger kan tage, når der arbejdes med børn og bevægelse. Hiim og Hippe betragter læring ud fra et kritisk, humanistisk udgangspunkt (2007). I forbindelse med målkategorien formulerer Hiim og Hippe:

"Målenes funktion drejer sig snarere om klarlæggelse og bevidstgørelsen iforhold til, hvad der er hensigten med undervisningen. Hvad er det som samfundet, skolen, lærerne, forældrene og eleverne selv ønsker at opnå?”(Hiim \& Hippe, 2007)

Målkategorien handler derfor også om en proces mod et mål, hvor vejen bliver til undervejs. Samtidig må pædagogen tage stilling til, hvorvidt mål(ene) for den pågældende pædagogiske aktivitet eller proces relaterer sig til samfundet, institutionen, forældrene eller til det enkelte barn/børnegruppen. Mål kan og bør knyttes til de generelle målsætninger for dagtilbuddenes bevægelsesarbejde, og dermed have til hensigt at stimulere børn til at opnå fortrolighed med kroppens muligheder, blandt andet for at bidrage til sundhed, trivsel og læring (Ministeriet for Børn, Undervisning og Ligestilling, 2016). Den gennemgåede litteratur gør gældende, at bevægelse har gavnlige virkninger på motorisk udvikling, psykosocial sundhed og kognition hos børn i o-6 års alderen (Sundhedsstyrelsen, 2016). Pædagogstyrede bevægelsesaktiviteter har en gavnlig effekt på motoriske færdigheder (Jones, Okely, Hinkley, Batterham, \& Burke, 2015) og kan bidrage til at udvikle børns sociale kompetencer (Tsangaridou, Zachopoulou, Liukkonen, Gråstén, \& Kokkonen, 2014) og til at fremme glæde (Sørensen, 2012). Arbejdet med børn og bevægelse kan i øvrigt indgå i forebyggelse af fedme, stimulering af motorisk udvikling, udvikling af Self-efficacy og lindring af stress. Bevægelse har i det hele taget positiv indflydelse på psykosociale faktorer hos børn (Copeland et al., 2012).

Den type fund giver et solidt belæg for, at bevægelse understøtter dagtilbudsmålsætninger om at fremme sundhed, trivsel og læring, og de bør have betydning i forhold til hvilke mål, der arbejdes med i praksis. Målene for pædagogisk praksis har en styringsfunktion. Når udgangspunktet, som her, er relationsmodellen, er det dog vigtigt at understrege, at indkredsede mål jævnligt vurderes og formuleres i sammenhæng med de andre kategorier i relationsmodellen. Der vil være et utal af veje til at indfri potentielle virkninger af børns bevægelse. En vigtig pointe er, at disse veje kan findes ved at arbejde med den interne afhængighed imellem kategorierne. Det arbejde kan give anledning til praksisnære diskussioner af børns bevægelse på basis af oplevelser og begivenheder i daglig pædagogisk praksis.

I forhold til vurderingskategorien peger Hiim og Hippe på et bredt vurderings- 
begreb, hvor både "en snæver pædagogisk måling af faktakundskaber og enkeltfærdigheder" (fx hoppehøjde)..., ... "en mere omfattende vurdering af barnets totale udvikling" og "et mere fuldstændigt billede af hele den pædagogisk situation" er relevant (2007). Vurderingsredskaber skal derfor understøtte ambitionerne om bevægelse, som facilitator af bestemte målsætninger. I den forbindelse skal de bidrage med meningsfulde svar på, hvad der virker med henblik på at skabe forståelse, refleksion, diskussion og læring. Det handler om, at vurderingsarbejdet aktivt skal bidrage til realisering af de ambitioner, der er formuleret for dagtilbuddenes bevægelsesindsatser og til en løsningsorienteret erkendelse af, hvad der holder, og hvad der ikke holder.

Den gennemgåede litteratur indeholder ikke mange bud på brugbare vurderingsredskaber. Her er der altså et område, som med fordel kan udvikles. Hiim og Hippes relationsmodel er i den sammenhæng et muligt teoretisk afsæt og der tegner sig en spændende udfordring i at udvikle vurderingsperspektiver, der åbner op for en vidensbaseret diskussion af, at bevægelse ikke kun er et redskab til at nå nyttemål i relation til børns sundhed, trivsel og læring, men også har en egenværdi - ikke sjældent knyttet til meningsfuldhed i nuet.

\section{BEGRAENSNINGER}

I tråd med artiklens metodiske tilgang beror diskussioner og konklusioner på forskning med forskellige metodiske tilgange. Der er inkluderet resultater og fund fra undersøgelser med større og mindre studiepopulationer, samt mere eller mindre kontrollerede undersøgelsesdesigns. Nogle studier præsenterer derfor viden af generel karakter, mens andre byder på dybdegående viden fra casestudier. Videnstyperne er ikke diskuteret. De inkluderede studier bidrager på et overordnet niveau til at finde forklarende mønstre på artiklens formål.

Udgangspunktet for denne artikel har været at kaste lys på danske forhold. Imidlertid har litteraturstudiet vist, at der er relativt få danske studier, som opfylder inklusionskriterierne. De inkluderede studier trækker derfor på data fra en række forskellige lande, hvorfor det kan diskuteres, hvorvidt artiklen i særlig grad kaster lys på danske forhold. Forskelle i kulturer, organiseringen af dagtilbud, formål med dagtilbud, pædagogers uddannelsesbaggrund, socioøkonomiske forskelle er nogle af de forhold, der varierer fra land til land. Det kan have konsekvenser for, i hvilken udstrækning artiklens fund kan overføres til en dansk sammenhæng.

Brugen af relationsmodellen som teoretisk ramme har tjent det formål at sætte resultaterne ind i en didaktisk kontekst i danske dagtilbud. Det greb har eventuelt forsimplet fremstillingen. Dels har det været vanskeligt at tilordne resultaterne entydigt i relationsmodellens seks kategorier, og dels skal kategorierne altid skal ses i relation til hinanden. 
Tager man disse begrænsninger til efterretning, skal konklusionerne i denne artikel ses som sandsynlige mønstre og faktorer, som pædagoger med fordel kan arbejde med, når det handler om at skabe bevægelsesmuligheder for børn.

\section{KONKLUSION}

Artiklens ærinde har været at undersøge hvilke faktorer, der har betydning for pædagogers didaktiske arbejde med at øge børns muligheder for bevægelse. Hiim og Hippes didaktiske relationsmodel (Hiim \& Hippe, 2007) har tjent som teoretisk ramme for en diskussion af artiklens resultater, og der konkluderes på baggrund af samme.

Pædagoger har mulighed for at præge børns læringsforudsætninger ved aktivt at inddrage forældre i arbejdet med bevægelse i dagtilbud og ved at præge forældres interesse i bevægelsesområdet og de aktiviteter, som de tager fat i sammen med børnene i fritiden. Yderligere ses det, at køn har en betydning, og at drenge typisk er mere fysisk aktive end piger.

Rammefaktorer diskuteres i artiklen i tre temaer: 1) Pædagogen som rollemodel, hvor det viser sig, at pædagogens egen interesse, involvering og engagement i bevægelse, viden om bevægelse, personlig bevægelsespraksis og den måde pædagogen fremstår aktiv eller inaktiv blandt børnene har stor betydning for børns bevægelsespraksis. 2) Læringsmiljøets fysiske udformning, hvor det tyder på, at udendørs leg giver anledning til mere bevægelse med højere intensitet end indendørsleg. Udendørsarealers størrelse og fysiske udformning af bevægelsesmiljøer har betydning for mængden af børns bevægelse i dagtilbud. Yderligere tyder det på, at det pædagogiske personale har en særlig udfordring i forbindelse med dårligt vejr, og når der ikke er pædagoger nok pr. barn. 3) Politikker, strategier og uddannelse, hvor der peges på, at disse påvirker pædagogers adfærd og muligheder for at øge mængden af børns bevægelse i dagtilbud. De giver pædagoger mulighed for at sætte mål for det enkelte barns bevægelsesmængde. Pædagoger angiver selv, at dagtilbud har en opgave i at tage ansvar for børns bevægelse, men der er tegn på, at en af barriererne for børns bevægelse er manglende uddannelse hos pædagogerne. Politikker, strategier og uddannelse kan anses som redskaber, der kan skabe ny bevægelsespraksis hos pædagoger.

I relation til Indhold og læreprocesser viser det sig, at der ikke er entydige fund vedrørende betydningen af henholdsvis fri leg og struktureret aktivitet. Noget forskning peger på, at pædagogstyrede aktiviteter højner børns mængde af bevægelse, mens anden forskning viser, at fx udendørs fri leg er kilde til en stor del af børns bevægelse. Yderligere ses det, at pædagogstyrede aktiviteter ikke nødvendigvis medfører øget bevægelse hos børn. Således er der ikke entydig retning i forskningen vedrørende betydningen af fri leg eller struktureret aktivitet, hvorfor 
både pædagogstyrede aktiviteter og fri leg bør prioriteres.

Opsummerende vedrørende mål og vurdering viser forskningen, at bevægelse i pædagogisk praksis kan anvendes til at udvikle børns motorik, psykosocial sundhed, kognition, sociale kompetencer og Self-efficacy. Samtidig kan bevægelse i pædagogisk praksis være med til at forebygge fedme og lindre stress. Disse effekter bør have betydning i forhold til hvilke mål, der arbejdes med i praksis og efterfølgende de parametre, hvormed pædagoger vurderer praksis. Det understreges, at mål og vurderingskriterier i pædagogisk praksis har stærk relation til og skal defineres i sammenhæng med de andre kategorier i den didaktiske relationsmodel. Det arbejde kan give anledning til centrale praksisnære diskussioner af børns bevægelse på basis af oplevelser og begivenheder i daglig pædagogisk praksis. Der tegner sig en spændende udfordring i at udvikle vurderingsperspektiver, der åbner for en vidensbaseret diskussion af, at bevægelse ikke kun er et redskab til at nå nyttemål, men også har en egenværdi.

Artiklen identificerer og diskuterer en række didaktiske faktorer, som i den nuværende forskningslitteratur markeres som vigtige i arbejdet med at øge mulighederne for børns bevægelse i dagtilbud. Der peges på, at der er brug for at kvalificere det pædagogiske personale på bevægelsesområdet, eksempelvis ved efteruddannelse. Yderligere forskning, meget gerne i danske sammenhænge, kan generere mere viden om, hvilke kompetencer det er væsentlige at udvikle, for at pædagogisk personale i endnu højere grad kan bidrage til at øge børns muligheder for bevægelse i dagtilbud, samt hvordan bevægelse i styrket omfang kan implementeres i pædagogisk praksis. 
BILAG 1:

Tabel 7: Oversigt over inkluderede studier fordelt på år, forfatter(e), land(e), studiedesign og deltagere/antal studier i review.

\begin{tabular}{|c|c|c|c|c|c|}
\hline År & Forfatter(e) & Titel & Land(e) & Studiedesign & $\begin{array}{l}\text { Deltagere / Antal } \\
\text { studier i review }\end{array}$ \\
\hline 2016 & Bjørgen & $\begin{array}{l}\text { Physical activity in light of affor- } \\
\text { dances in outdoor environments: } \\
\text { qualitative observation studies of } \\
3-5 \text { years olds in kindergarten }\end{array}$ & Norge & $\begin{array}{l}\text { Kvalitativt: } \\
\text { Observationer og } \\
\text { videooptagelser }\end{array}$ & $\begin{array}{l}24 \text { børn I ét } \\
\text { dagtilbud }\end{array}$ \\
\hline \multirow[t]{5}{*}{2016} & \multirow[t]{5}{*}{ Howie et al. } & \multirow[t]{5}{*}{$\begin{array}{l}\text { A Tale of } 2 \text { Teachers: A } \\
\text { Preschool Physical } \\
\text { Activity Intervention Case Study }\end{array}$} & \multirow[t]{5}{*}{ Australien } & \multicolumn{2}{|c|}{$\begin{array}{l}\text { Mixed Methods: } \\
\text { Interventionsstudie i } 2 \text { dagtilbud } \\
\text { Kvantitativt: }\end{array}$} \\
\hline & & & & Observationer & 2 pædagoger \\
\hline & & & & Spørgeskema & 2 pædagoger \\
\hline & & & & \multicolumn{2}{|l|}{ Kvalitativt: } \\
\hline & & & & Felt noter & 2 pædagoger \\
\hline \multirow[t]{6}{*}{2016} & \multirow[t]{6}{*}{ Pape et al. } & \multirow{6}{*}{$\begin{array}{l}\text { Potentials of physical activity } \\
\text { promotion in preschools - an } \\
\text { overview of results of an ethno- } \\
\text { graphic observation }\end{array}$} & \multirow[t]{6}{*}{ Tyskland } & \multicolumn{2}{|c|}{$\begin{array}{l}\text { Mixed Methods: } \\
\text { Kvantitative metoder til udvælgelse af } \\
\text { dagtilbud }\end{array}$} \\
\hline & & & & $\begin{array}{l}\text { Spørgeskema } \\
\text { til pædagoger i } \\
\text { dagtilbud }\end{array}$ & $\begin{array}{l}2415 \text { (svarpro- } \\
\text { cent:59\%) }\end{array}$ \\
\hline & & & & $\begin{array}{l}\text { Spørgeskema til } \\
\text { forældre }\end{array}$ & 363 forældre \\
\hline & & & & $\begin{array}{l}\text { Skridttæller til } \\
\text { børn (Pedometer) }\end{array}$ & 417 børn \\
\hline & & & & \multicolumn{2}{|c|}{$\begin{array}{l}\text { Kvalitativt til at udforske forskelle } \\
\text { mellem dagtilbud med og uden fokus på } \\
\text { fysisk aktivitet }\end{array}$} \\
\hline & & & & $\begin{array}{l}\text { Fokuseret } \\
\text { etnografisk } \\
\text { observation }\end{array}$ & $\begin{array}{l}\text { I alt } 4 \text { dagtilbud. } \\
2 \text { med fokus på } \\
\text { fysisk aktivi- } \\
\text { tet og } 2 \text { uden } \\
\text { fokus på fysisk } \\
\text { aktivitet }\end{array}$ \\
\hline 2016 & Pate et al. & $\begin{array}{l}\text { An Intervention to Increase } \\
\text { Physical Activity in Children }\end{array}$ & USA & $\begin{array}{l}\text { Kvantitativt: } \\
\text { Randomiseret kon- } \\
\text { trolleret fors } \varnothing \mathrm{g} \\
\text { Accelerometer }\end{array}$ & $\begin{array}{l}379 \text { børn i } 16 \\
\text { dagtilbud }\end{array}$ \\
\hline 2016 & Tonge et al. & $\begin{array}{l}\text { Correlates of children's objec- } \\
\text { tively measured physical activity } \\
\text { and sedentary behavior in early } \\
\text { childhood education and care } \\
\text { services: A systematic review }\end{array}$ & Australien & $\begin{array}{l}\text { Kvantitativt: } \\
\text { Systematisk } \\
\text { litteraturstudie }\end{array}$ & 27 studier \\
\hline 2016 & Tsangaridou & $\begin{array}{l}\text { Early childhood teachers' } \\
\text { views about teaching physical } \\
\text { education: challenges and } \\
\text { recommendations }\end{array}$ & Cypern & $\begin{array}{l}\text { Kvalitativt: } \\
\text { Interviews } \\
\text { Komparativ } \\
\text { caseanalyse }\end{array}$ & 4 pædagoger \\
\hline
\end{tabular}




\begin{tabular}{|c|c|c|c|c|c|}
\hline \multirow[t]{4}{*}{2015} & \multirow[t]{4}{*}{ Archer \& Siraj } & \multirow{4}{*}{$\begin{array}{l}\text { Measuring the quality of } \\
\text { movement-play in Early } \\
\text { Childhood Education settings: } \\
\text { Linking movement play and } \\
\text { neuroscience }\end{array}$} & \multirow[t]{4}{*}{ Storbritanien } & \multicolumn{2}{|l|}{$\begin{array}{l}\text { Mixed Methods: } \\
\text { Kvantitativt: }\end{array}$} \\
\hline & & & & $\begin{array}{l}\text { Interventionsstudi } \\
\text { indeholdende før- } \\
\text { og eftermålinger } \\
\text { med "the move- } \\
\text { ment-play scale" }\end{array}$ & 4 dagtilbud \\
\hline & & & & \multicolumn{2}{|l|}{ Kvalitativt: } \\
\hline & & & & $\begin{array}{l}\text { Ustrukturerede } \\
\text { interviews }\end{array}$ & $\begin{array}{l}\text { Ledere i de } 4 \\
\text { involverede } \\
\text { dagtilbud }\end{array}$ \\
\hline 2015 & Berg, S. & $\begin{array}{l}\text { Children's Activity Levels } \\
\text { in Different Playground } \\
\text { Environments: An Observational } \\
\text { Study in Four Canadian } \\
\text { Preschools }\end{array}$ & Canada & $\begin{array}{l}\text { Kvantitativt: } \\
\text { Observations- } \\
\text { studie }\end{array}$ & $\begin{array}{l}4 \text { dagtilbud } \\
129 \text { børn }\end{array}$ \\
\hline 2015 & $\begin{array}{l}\text { Elliot \& } \\
\text { Campbell }\end{array}$ & $\begin{array}{l}\text { 'Really on the ball': exploring } \\
\text { the implications of teachers' } \\
\text { PE-CPD experience }\end{array}$ & Storbritanien & $\begin{array}{l}\text { Kvalitativt: } \\
\text { Semistrukturerede } \\
\text { interviews }\end{array}$ & 4 pædagoger \\
\hline 2015 & $\begin{array}{l}\text { Fees, Fischer, } \\
\text { Haar \& Crowe }\end{array}$ & $\begin{array}{l}\text { Toddler Activity Intensity During } \\
\text { Indoor Free-Play: Stand and } \\
\text { Watch }\end{array}$ & USA & $\begin{array}{l}\text { Kvantitativt: } \\
\text { Observations- } \\
\text { studie }\end{array}$ & $\begin{array}{l}41 \text { børn i alderen } \\
16-36 \text { måneder I ét } \\
\text { dagtilbud }\end{array}$ \\
\hline 2015 & $\begin{array}{l}\text { Helen Little \& } \\
\text { Naomi Sweller }\end{array}$ & $\begin{array}{l}\text { Affordances for Risk-Taking and } \\
\text { Physical Activity in Australian } \\
\text { Early Childhood Education } \\
\text { Settings }\end{array}$ & Austalien & $\begin{array}{l}\text { Kvantitativt: } \\
\text { Spørgeskema- } \\
\text { undersøgelse }\end{array}$ & $\begin{array}{l}\text { Ejere, ledere } \\
\text { \& pædagoger } \\
\text { i Australske } \\
\text { dagtilbud. } \\
\text { I alt: } 245\end{array}$ \\
\hline 2015 & Jones et al. & $\begin{array}{l}\text { Promoting gross motor skills and } \\
\text { physical activity in childcare: A } \\
\text { translational randomized con- } \\
\text { trolled trial }\end{array}$ & Australien & $\begin{array}{l}\text { Kvantitativt: } \\
\text { Randomiseret } \\
\text { kontrolleret fors } ø \text { g. } \\
\text { Interventions- } \\
\text { studie } \\
\text { Evaluerings- } \\
\text { skemaer til } \\
\text { pædagoger } \\
\text { Fysiske test og } \\
\text { accelerome- } \\
\text { ter-målinger af } \\
\text { børn }\end{array}$ & $\begin{array}{l}\text { Interventions- } \\
\text { gruppe: } 77 \text { børn i } 2 \\
\text { dagtilbud } \\
\text { Kontrolgruppe: } \\
73 \text { børn i } 2 \\
\text { dagtilbud }\end{array}$ \\
\hline 2014 & $\begin{array}{l}\text { Eva Johansson } \\
\text { \& Gunvor } \\
\text { Løkken }\end{array}$ & $\begin{array}{l}\text { Sensory Pedagogy: } \\
\text { Understanding and encountering } \\
\text { children through the senses }\end{array}$ & Norge & $\begin{array}{l}\text { Kvalitativt: } \\
\text { Obervationsstudie }\end{array}$ & $\begin{array}{l}\text { En stue i et norsk } \\
\text { dagtilbud }\end{array}$ \\
\hline 2014 & $\begin{array}{l}\text { Froelich Chow \& } \\
\text { Humbert }\end{array}$ & $\begin{array}{l}\text { Perceptions of early childhood } \\
\text { educators: Factors influencing } \\
\text { the promotion of physical activity } \\
\text { opportunities in Canadian rural } \\
\text { care centers }\end{array}$ & Canada & $\begin{array}{l}\text { Kvalitativt: } \\
\text { Interviews og } \\
\text { dokumentanalyse }\end{array}$ & $\begin{array}{l}8 \text { ledere/ pæ- } \\
\text { dagoger fra } \\
8 \text { deltagende } \\
\text { dagilbud }\end{array}$ \\
\hline 2014 & Howie et al. & $\begin{array}{l}\text { The 3-year evolution of a pre- } \\
\text { school physical activity } \\
\text { intervention through a collab- } \\
\text { orative partnership between } \\
\text { research interventionists and } \\
\text { preschool teachers }\end{array}$ & USA & $\begin{array}{l}\text { Kvantitativt: } \\
\text { Randomiseret } \\
\text { kontrolleret forsøg }\end{array}$ & 16 dagtilbud \\
\hline 2014 & Reunamo et al. & $\begin{array}{l}\text { Children's physical activity in } \\
\text { day care and preschool }\end{array}$ & Finland & $\begin{array}{l}\text { Kvantitativt: } \\
\text { Observationer og } \\
\text { pædagogstyrede } \\
\text { interviews }\end{array}$ & $\begin{array}{l}823 \text { børn I } 50 \\
\text { dagtilbud }\end{array}$ \\
\hline
\end{tabular}




\begin{tabular}{|c|c|c|c|c|c|}
\hline 2014 & $\begin{array}{l}\text { Tsangaridou } \\
\text { et al. }\end{array}$ & $\begin{array}{l}\text { Developing preschoolers' social } \\
\text { skills through cross-cultural } \\
\text { physical education intervention }\end{array}$ & $\begin{array}{l}\text { Cypern, } \\
\text { Grækenland } \\
\text { og Finland }\end{array}$ & $\begin{array}{l}\text { Kvantitativt: } \\
\text { Spørgeskema } \\
\text { til forældre og } \\
\text { pædagoger }\end{array}$ & $\begin{array}{l}286 \text { børn fordelt } \\
\text { på } 6 \text { dagtilbud }-2 \text { i } \\
\text { hvert land }\end{array}$ \\
\hline 2013 & $\begin{array}{l}\text { Coleman \& } \\
\text { Dyment }\end{array}$ & $\begin{array}{l}\text { Factors that limit and enable } \\
\text { preschool-aged children's phys- } \\
\text { ical activity on child care centre } \\
\text { playgrounds }\end{array}$ & Australien & $\begin{array}{l}\text { Kvalitativt: } \\
\text { Dybdegående } \\
\text { semistrukturerede } \\
\text { interviews }\end{array}$ & $\begin{array}{l}\text { I alt } 16 \text { pædagoger. } \\
4 \text { i hvert af } 4 \text { delta- } \\
\text { gende dagtilbud. }\end{array}$ \\
\hline 2013 & $\begin{array}{l}\text { De Craemer } \\
\text { et al. }\end{array}$ & $\begin{array}{l}\text { Physical activity and beverage } \\
\text { consumption in preschoolers: } \\
\text { focus groups with parents and } \\
\text { teachers }\end{array}$ & $\begin{array}{l}\text { Belgien, } \\
\text { Bulgarien, } \\
\text { Tyskland, } \\
\text { Grækenland, } \\
\text { Polen og } \\
\text { Spanien }\end{array}$ & $\begin{array}{l}\text { Kvalitativt: } \\
\text { Semi- } \\
\text { strukturerede } \\
\text { interviews }\end{array}$ & $\begin{array}{l}4 \text { fokusgrupper } \\
\text { med forældre og } 3 \\
\text { fokusgrupper med } \\
\text { pædagoger i hvert } \\
\text { land } \\
\text { I alt: } \\
122 \text { forældre og } \\
87 \text { pædagoger }\end{array}$ \\
\hline 2013 & $\begin{array}{l}\text { Elliott S. } \\
\text { Gordon, Patricia } \\
\text { Tucker, Shauna } \\
\text { M. Burke \& } \\
\text { Albert V. Carron }\end{array}$ & $\begin{array}{l}\text { Effectiveness of Physical Activity } \\
\text { Interventions for Preschoolers: } \\
\text { A Meta-Analysis }\end{array}$ & Canada & $\begin{array}{l}\text { Kvantitativt: } \\
\text { Meta-analyse. } \\
\text { Litteraturstudie }\end{array}$ & $\begin{array}{l}15 \text { inkluderede } \\
\text { studier }\end{array}$ \\
\hline 2013 & $\begin{array}{l}\text { Olesen, } \\
\text { Kristensen, } \\
\text { Korsholm, \& } \\
\text { Froberg }\end{array}$ & $\begin{array}{l}\text { Physical Activity in Children } \\
\text { Attending Preschools }\end{array}$ & Danmark & $\begin{array}{l}\text { Kvantitativt: } \\
\text { Tværsnitsstudie } \\
\text { accelerometer }\end{array}$ & $\begin{array}{l}426 \text { børn I alderen } \\
5-6 \text { år fra } 42 \\
\text { danske børnehaver }\end{array}$ \\
\hline 2013 & $\begin{array}{l}\text { Sevimli-Celik } \\
\text { \& James E. } \\
\text { Johnson }\end{array}$ & $\begin{array}{l}\text { "I Need to Move and So Do the } \\
\text { Children" }\end{array}$ & USA & $\begin{array}{l}\text { Kvantitativt: } \\
\text { Spørgeskema- } \\
\text { undersøgelse }\end{array}$ & $\begin{array}{l}149 \text { pædagoger } \\
\text { (svarprocent: } 59 \% \text { ) }\end{array}$ \\
\hline 2013 & $\begin{array}{l}\text { Van } \\
\text { Cauwenberghe, } \\
\text { De Craemer, } \\
\text { De Decker, De } \\
\text { Bourdeaudhuij, } \\
\text { \& Cardon }\end{array}$ & $\begin{array}{l}\text { The impact of a teacher-led } \\
\text { structured physical activity } \\
\text { session on preschoolers' seden- } \\
\text { tary and physical activity levels }\end{array}$ & Belgien & $\begin{array}{l}\text { Kvantitativt } \\
\text { Accelerometer- } \\
\text { målinger }\end{array}$ & $\begin{array}{l}200 \text { børn I alderen } \\
4-5 \text { år fra } 26 \text { belgi- } \\
\text { ske børnehaver }\end{array}$ \\
\hline 2012 & Copeland et al. & $\begin{array}{l}\text { Physical activity in child-care } \\
\text { centers: do teachers hold the } \\
\text { key to the playground? }\end{array}$ & USA & $\begin{array}{l}\text { Kvalitativt: } \\
9 \text { fokus } \\
\text { gruppeinterviews } \\
13 \text { En-til-en } \\
\text { interviews }\end{array}$ & I alt 49 pædagoger \\
\hline 2012 & Pisha & $\begin{array}{l}\text { Teachers' Beliefs Related to } \\
\text { Activity Play in the Preschool } \\
\text { Setting: A Phenomenological } \\
\text { Investigation }\end{array}$ & USA & $\begin{array}{l}\text { Kvalitativt: } \\
\text { Dybdegående } \\
\text { fænomenologiske } \\
\text { interviews }\end{array}$ & 13 pædagoger \\
\hline \multirow[t]{4}{*}{2012} & \multirow{4}{*}{$\begin{array}{l}\text { Sugiyama, } \\
\text { Okely, Masters, } \\
\text { \& Moore }\end{array}$} & \multirow{4}{*}{$\begin{array}{l}\text { Attributes of Child Care Centers } \\
\text { and Outdoor Play Areas } \\
\text { Associated With Preschoolers' } \\
\text { Physical Activity and Sedentary } \\
\text { Behavior }\end{array}$} & \multirow[t]{4}{*}{ Australien } & \multicolumn{2}{|l|}{ Kvantitativt: } \\
\hline & & & & Accelerometer & $\begin{array}{l}107 \text { børn fra } 10 \\
\text { dagtilbud }\end{array}$ \\
\hline & & & & Spørgeskema & $\begin{array}{l}\text { Lederne af de } 10 \\
\text { dagtilbud }\end{array}$ \\
\hline & & & & $\begin{array}{l}\text { Planer over } \\
\text { udendørs legea- } \\
\text { real indsamlet }\end{array}$ & 10 dagtilbud \\
\hline
\end{tabular}




\begin{tabular}{|c|c|c|c|c|c|}
\hline \multirow[t]{6}{*}{2012} & \multirow[t]{6}{*}{ Sørensen } & \multirow[t]{6}{*}{$\begin{array}{l}\text { Børns fysiske aktivitet i } \\
\text { børnehaver }\end{array}$} & \multirow[t]{6}{*}{ Danmark } & \multicolumn{2}{|l|}{$\begin{array}{l}\text { Mixed Methods: } \\
\text { Kvantitativt: }\end{array}$} \\
\hline & & & & ECERS & 43 børnehaver \\
\hline & & & & \multicolumn{2}{|l|}{ Kvalitativt: } \\
\hline & & & & $\begin{array}{l}\text { Dokument- } \\
\text { analyser }\end{array}$ & $\begin{array}{l}3 \text { udvalgte } \\
\text { børnehaver }\end{array}$ \\
\hline & & & & $\begin{array}{l}\text { Semi- } \\
\text { strukturerede } \\
\text { interviews }\end{array}$ & $\begin{array}{l}\text { Ledere og } \\
\text { pædagoger } \\
\text { i } 3 \text { udvalgte } \\
\text { børnehaver }\end{array}$ \\
\hline & & & & $\begin{array}{l}\text { Video- } \\
\text { observationer }\end{array}$ & $\begin{array}{l}3 \text { udvalgte } \\
\text { børnehaver }\end{array}$ \\
\hline 2012 & $\begin{array}{l}\text { Van } \\
\text { Cauwenberghe, } \\
\text { Labarque, } \\
\text { Gubbels, De } \\
\text { Bourdeaudhuij, } \\
\text { \& Cardon }\end{array}$ & $\begin{array}{l}\text { The impact of a teacher-led } \\
\text { structured physical activity } \\
\text { session on preschoolers' seden- } \\
\text { tary and physical activity levels }\end{array}$ & Belgien & $\begin{array}{l}\text { Kvantitativt: } \\
\text { Accelerometer- } \\
\text { målinger }\end{array}$ & $\begin{array}{l}244 \text { børn i } 28 \\
\text { dagtilbud }\end{array}$ \\
\hline 2011 & Musatti \& Meyer & $\begin{array}{l}\text { Sharing attention and activities } \\
\text { among toddlers: the spatial } \\
\text { dimension of the setting and the } \\
\text { educator's role }\end{array}$ & Italien & $\begin{array}{l}\text { Kvalitativ: } \\
\text { Analyser foretager } \\
\text { på baggrund af } 54 \\
\text { videoobservationer } \\
\text { over en periode på } \\
2 \text { år og pædago- } \\
\text { gers dagbøger }\end{array}$ & 15 børn \\
\hline 2011 & $\begin{array}{l}\text { Nicaise, Kahan } \\
\& \text { Sallis }\end{array}$ & $\begin{array}{l}\text { Correlates of moderate-to-vig- } \\
\text { orous physical activity among } \\
\text { preschoolers during unstruc- } \\
\text { tured outdoor play periods }\end{array}$ & USA & $\begin{array}{l}\text { Kvantitativt: } \\
\text { Observationsstudie } \\
\text { Observation } \\
\text { System for } \\
\text { Recording Physical } \\
\text { Activity in Children } \\
\text { - Preschool } \\
\text { (OSRSAC-P) }\end{array}$ & $\begin{array}{l}51 \text { børn I et ameri- } \\
\text { kansk dagtilbud }\end{array}$ \\
\hline 2010 & $\begin{array}{l}\text { Van Zandvoort, } \\
\text { Tucker,Irwin \& } \\
\text { Burke }\end{array}$ & $\begin{array}{l}\text { Physical activity at daycare: } \\
\text { issues, challenges and } \\
\text { perspectives }\end{array}$ & Canada & $\begin{array}{l}\text { Kvalitativt: } \\
\text { Semi-strukturerede } \\
\text { fokusgruppeinter- } \\
\text { views }\end{array}$ & 54 pædagoger \\
\hline 2009 & $\begin{array}{l}\text { Brown, Googe, } \\
\text { Mclver, \& Rathel }\end{array}$ & $\begin{array}{l}\text { Effects of Teacher-Encouraged } \\
\text { Physical Activity on Preschool } \\
\text { Playgrounds }\end{array}$ & USA & $\begin{array}{l}\text { Kvantitativt: } \\
\text { Interventionsstudie } \\
\text { med observationer } \\
\text { over en 3-årig } \\
\text { periode }\end{array}$ & 5 børn \\
\hline 2009 & Brown et al. & $\begin{array}{l}\text { Social and Environmental } \\
\text { Factors Associated With } \\
\text { Preschoolers' Nonsedentary } \\
\text { Physical Activity }\end{array}$ & USA & $\begin{array}{l}\text { Kvantitativt: } \\
\text { Observationer }\end{array}$ & $\begin{array}{l}\text { Børn I } 24 \text { ameri- } \\
\text { kanske dagtilbuid }\end{array}$ \\
\hline
\end{tabular}




\begin{tabular}{|c|c|c|c|c|c|}
\hline \multirow[t]{7}{*}{2009} & \multirow[t]{7}{*}{ Dowda et al. } & \multirow{7}{*}{$\begin{array}{l}\text { Policies and Characteristics } \\
\text { of the Preschool Environment } \\
\text { and Physical Activity of Young } \\
\text { Children }\end{array}$} & \multirow[t]{7}{*}{ USA } & \multicolumn{2}{|l|}{$\begin{array}{l}\text { Mixed Methods: } \\
\text { Kvantitativt: }\end{array}$} \\
\hline & & & & Accelerometer & $\begin{array}{l}299 \text { børn i } 24 \\
\text { dagtilbud }\end{array}$ \\
\hline & & & & Observationer & $\begin{array}{l}476 \text { børn i } 24 \\
\text { dagtilbud }\end{array}$ \\
\hline & & & & $\begin{array}{l}\text { Måling af } \\
\text { dagtilbuddenes } \\
\text { arealer }\end{array}$ & 24 dagtilbud \\
\hline & & & & Spørgeskema & $\begin{array}{l}\text { Deltagende børn } \\
\text { forældre }\end{array}$ \\
\hline & & & & \multicolumn{2}{|l|}{ Kvalitativt: } \\
\hline & & & & $\begin{array}{l}\text { Strukturerede } \\
\text { Interviews }\end{array}$ & $\begin{array}{l}\text { Et medlem fra } \\
\text { administrationen } \\
\text { fra hver af de del- } \\
\text { tagende dagtilbud. } \\
\text { I alt } 24\end{array}$ \\
\hline 2009 & $\begin{array}{l}\text { Lougue \& } \\
\text { Harvey }\end{array}$ & $\begin{array}{l}\text { Preschool Teachers' Views of } \\
\text { Active Play }\end{array}$ & USA & $\begin{array}{l}\text { Kvalitativt: } \\
\text { Spørgeskema- } \\
\text { undersøgelse med } \\
\text { åbne spørgsmål. }\end{array}$ & $\begin{array}{l}98 \text { pædagoger } \\
\text { I forskellige } \\
\text { dagtilbud }\end{array}$ \\
\hline 2009 & Perry \& Branum & $\begin{array}{l}\text { "Sometimes I Pounce on Twigs } \\
\text { Because I'm a Meat Eater", } \\
\text { Supporting Physically Active } \\
\text { Play and Outdoor Learning }\end{array}$ & USA & $\begin{array}{l}\text { Kvalitativt: } \\
\text { Observationsstudie }\end{array}$ & $\begin{array}{l}2 \text { mindre bør- } \\
\text { ne-grupper i } 1 \\
\text { dagtilbud. }\end{array}$ \\
\hline 2009 & $\begin{array}{l}\text { Williams, } \\
\text { Carter, Kibbe, \& } \\
\text { Dennison }\end{array}$ & $\begin{array}{l}\text { Increasing Physical Activity } \\
\text { in Preschool: A Pilot Study to } \\
\text { Evaluate Animal Trackers }\end{array}$ & USA & $\begin{array}{l}\text { Kvantitativt: } \\
\text { Interventionsstudie } \\
\text { Evalueringsskemae } \\
\text { til pædagoger }\end{array}$ & $\begin{array}{l}270 \text { børn } \\
32 \text { pædagoger I } \\
9 \text { dagtilbud }\end{array}$ \\
\hline 2008 & Bower et al. & $\begin{array}{l}\text { The Childcare Environment and } \\
\text { Children's Physical activity }\end{array}$ & USA & $\begin{array}{l}\text { Kvantitativt: } \\
\text { Observationer }\end{array}$ & $\begin{array}{l}20 \text { tilfældigt ud- } \\
\text { valgte dagtilbud }\end{array}$ \\
\hline 2008 & $\begin{array}{l}\text { Hannon \& } \\
\text { Brown }\end{array}$ & $\begin{array}{l}\text { Increasing preschoolers' } \\
\text { physical activity intensities: An } \\
\text { activity-friendly preschool play- } \\
\text { ground intervention }\end{array}$ & USA & $\begin{array}{l}\text { Kvantitativt: } \\
\text { Interventionsstudie } \\
\text { med tilførelse af } \\
\text { udstyr til udendørs } \\
\text { legepladser. Før- } \\
\text { og eftermålinger } \\
\text { foretaget med } \\
\text { accelerometer }\end{array}$ & 64 børn \\
\hline 2006 & $\begin{array}{l}\text { Lissau, } \\
\text { Hesse, Juhl, \& } \\
\text { Davidsen }\end{array}$ & $\begin{array}{l}\text { Mad og fysisk aktivitet } \\
\text { i børnehaver, skoler og fritids- } \\
\text { hjem/ skolefritidsordninger }\end{array}$ & Danmark & $\begin{array}{l}\text { Kvantitativt: } \\
\text { Spørgeskema- } \\
\text { undersøgelse i } \\
\text { danske børnehave, } \\
\text { skoler og SFO'er pa } \\
\text { tværs af landet }\end{array}$ & $\begin{array}{l}1323 \\
\text { Deltagere } \\
\text { bestående af } \\
\text { skole/ instituti- } \\
\text { ons-leder eller } \\
\text { pædagoger. }\end{array}$ \\
\hline
\end{tabular}




\section{REFERENCER}

Archer, C., \& Siraj, I. (2015). Measuring the quality of movement-play in early childhood education settings: Linking movement-play and neuroscience. European Early Childhood Education Research Journal, 23(1), 21-42.

Berg, S. (2015). Children's activity levels in different playground environments: An observational study in four canadian preschools. Early Childhood Education Journal, 43(4), 281-287. doi:10.1007/s10643-014-0654-5

Bjørgen, K. (2016). Physical activity in light of affordances in outdoor environments: Qualitative observation studies of 3-5 years olds in kindergarten. SpringerPlus, 5(1) doi:10.1186/s40064-016-2565-y

Bower, J. K., Hales, D. P., Tate, D. F., Rubin, D. A., Benjamin, S. E., \& Ward, D. S. (2008). The childcare environment and children's physical activity. American Journal of Preventive Medicine, 34(1), 23-29.

Brown, W. H., Pfeiffer, K. A., McIver, K. L., Dowda, M., Addy, C. L., \& Pate, R. R. (2009). Social and environmental factors associated with preschoolers' nonsedentary physical activity. Child Development, 8o(1), 45-58.

Brown, W. H., Googe, H. S., McIver, K. L., \& Rathel, J. M. (2009). Effects of teacher-encouraged physical activity on preschool playgrounds. Journal of Early Intervention, 31(2), 126-145.

Coleman, B., \& Dyment, J. E. (2013). Factors that limit and enable preschool-aged children's physical activity on child care centre playgrounds. Journal of Early Childhood Research, 11(3), 203-221. doi:10.1177/1476718X12456250

Copeland, K. A., Kendeigh, C. A., Saelens, B. E., Kalkwarf, H. J., \& Sherman, S. N. (2012). Physical activity in child-care centers: Do teachers hold the key to the playground? $\mathrm{He}$ alth Education Research, 27(1), 81-100.

Danmarks Evalueringsinstitut. (2012). Læreplaner i praksis-Daginstitutionernes arbejde med pædagogiske læreplaner. Copenhagen: Rosendahls-Schultz Grafisk a/s.

Danmarks Evalueringsinstitut. (2016). o-2 årige børns læring. København: Rosendahls.

De Craemer, M., De Decker, E., De Bourdeaudhuij, I., Deforche, B., Vereecken, C., Duvinage, K., .. . Cardon, G. (2013). Physical activity and beverage consumption in preschoolers: Focus groups with parents and teachers. BMC Public Health, 13(1) doi:10.1186/14712458-13-278

Dowda, M., Brown, W. H., McIver, K. L., Pfeiffer, K. A., O’Neill, J. R., Addy, C. L., \& Pate, R. R. (2009). Policies and characteristics of the preschool environment and physical activity of young children. Pediatrics, 123(2), e261-6. doi:10.1542/peds.2008-2498 [doi]

Elliot, D. L., \& Campbell, T. (2015). "Really on the ball": Exploring the implications of teachers' PE-CPD experience. Sport, Education and Society, 20(3), 381-397.

Fees, B. S., Fischer, E., Haar, S., \& Crowe, L. K. (2015). Toddler activity intensity during indoor free-play: Stand and watch. Journal of Nutrition Education and Behavior, 47(2), 
170-175. doi:10.1016/j.jneb.2014.08.015

Froehlich Chow, A., \& Humbert, M. L. (2014). Perceptions of early childhood educators: Factors influencing the promotion of physical activity opportunities in canadian rural care centers. Child Indicators Research, 7(1), 57-73. doi:10.1007/s12187-013-9202-x

Giske, R., Tjensvoll, M., \& Dyrstad, S. M. (2010). Fysisk aktivitet i barnehagen: Et casestudium av daglig fysisk aktivitet $i$ en avdeling med 5 -åringer.

Gordon, E. S., Tucker, P., Burke, S. M., \& Carron, A. V. (2013). Effectiveness of physical activity interventions for preschoolers: A meta-analysis. Research Quarterly for Exercise and Sport, 84(3), 287-294.

Grøntved, A., Pedersen, G., Andersen, L., Kristensen, P., Møller, N., \& Froberg, K. (2009). Personal characteristics and demographic factors associated with objectively measured physical activity in children attending preschool. Pediatric Exercise Science, (21), 209.

Hannon, J. C., \& Brown, B. B. (2008). Increasing preschoolers' physical activity intensities: An activity-friendly preschool playground intervention. Preventive Medicine, 46(6), 532-536. doi:10.1016/j.ypmed.2008.01.006

Hiim, H., \& Hippe, E. (2007). Læring gennem oplevelse, forståelse og handling : En studiebog i didaktik (2nd ed.). Kbh.: Gyldendal.

Howie, E. K., Brewer, A., Brown, W. H., Pfeiffer, K. A., Saunders, R. P., \& Pate, R. R. (2014). The 3-year evolution of a preschool physical activity intervention through a collaborative partnership between research interventionists and preschool teachers. Health Education Research, 29(3), 491-502.

Howie, E. K., Brewer, A. E., Dowda, M., McIver, K. L., Saunders, R. P., \& Pate, R. R. (2016). A tale of 2 teachers: A preschool physical activity intervention case study. Journal of School Health, 86(1), 23-30.

Johansson, E., \& Løkken, G. (2014). Sensory pedagogy: Understanding and encountering children through the senses. Educational Philosophy and Theory, 46(8), 886-897. doi: 10.1080/00131857.2013.783776

Jones, R. A., Okely, A. D., Hinkley, T., Batterham, M., \& Burke, C. (2015). Promoting gross motor skills and physical activity in childcare: A translational randomized controlled trial. Journal of Science and Medicine in Sport,

Jørgensen, P. S., \& Rienecker, L. (2014). Den gode opgave Samfundslitteratur, Frederiksberg.

Klafki, W. (2011). Dannelsesteori og didaktik : Nye studier (3rd ed.). Århus: Klim.

Lissau, I., Hesse, U., Juhl, M., \& Davidsen, M. (2006). Mad og fysisk aktivitet i børnehaver, skoler og fritidshjem/skolefritidsordninger. Statens Institut for Folkesundhed, København,

Little, H., \& Sweller, N. (2015). Affordances for risk-taking and physical activity in australian early childhood education settings. Early Childhood Education Journal, 43(4), 


\section{7-345. doi:10.1007/s10643-014-0667-0}

Logue, M. E., \& Harvey, H. (2009). Preschool teachers' views of active play. Journal of Research in Childhood Education, 24(1), 32-49.

Ministeriet for Børn, Undervisning og Ligestilling. (2016). Bekendtgørelse af lov om dag-, fritids- og klubtilbud m.v. til børn og unge. LBK nr 748 af 20/o6/2016

Musatti, T., \& Mayer, S. (2011). Sharing attention and activities among toddlers: The spatial dimension of the setting and the educator's role. European Early Childhood Education Research Journal, 19(2), 207-221.

Nicaise, V., Kahan, D., \& Sallis, J. F. (2011). Correlates of moderate-to-vigorous physical activity among preschoolers during unstructured outdoor play periods. Preventive Medicine, 53(4-5), 309-315. doi:10.1016/j.ypmed.2011.08.018 [doi]

Olesen, L. G., Kristensen, P. L., Korsholm, L., \& Froberg, K. (2013). Physical activity in children attending preschools. Pediatrics, 132(5), e1310-8. doi:10.1542/peds.2012-3961 [doi]

Pape, N., Sterdt, E., Azouagh, K., Kramer, S., Walter, U., Urban, M., \& Werning, R. (2016). Potentials of physical activity promotion in preschools - an overview of results of an ethnographic observation. European Early Childhood Education Research Journal, 24(4), 581-591. doi:10.1080/1350293X.2016.1189724

Pate, R. R., Brown, W. H., Pfeiffer, K. A., Howie, E. K., Saunders, R. P., Addy, C. L., \& Dowda, M. (2016). An intervention to increase physical activity in children: A randomized controlled trial with 4-year-olds in preschools. American Journal of Preventive Medicine,

Pawson, R., Greenhalgh, T., Harvey, G., \& Walshe, K. (2005). Realist review--a new method of systematic review designed for complex policy interventions. Journal of Health Services Research \& Policy, 10 Suppl 1, 21-34. doi:10.1258/1355819054308530 [doi]

Perry, J. P., \& Branum, L. (2009). “ Sometimes I pounce on twigs because I'm a meat eater": Supporting physically active play and outdoor learning. American Journal of Play, 2(2), 195-214.

Pisha, L. E. (2012). Teachers' beliefs related to activity play in the preschool setting: A phenomenological investigation Available from EBSCOhost; eric.

Reunamo, J., Hakala, L., Saros, L., Lehto, S., Kyhälä, A., \& Valtonen, J. (2014). Children's physical activity in day care and preschool. Early Years, 34(1), 32-48. doi:10.1080/095 75146.2013.843507

Sevimli-Celik, S., \& Johnson, J. E. (2013). “I need to move and so do the children". International Education Studies, 6(5), 1-10. doi:10.5539/ies.v6n5p1

Sørensen, H. V. (2012). Børns fysiske aktivitet $i$ børnehaver. En analyse af 5-6 årige børns muligheder og betingelser for fysisk aktivitet i forskellige børnehaver og den fysiske aktivitets betydning for børns udvikling.(Ph.d.).

Sugiyama, T., Okely, A. D., Masters, J. M., \& Moore, G. T. (2012). Attributes of child care 
centers and outdoor play areas associated with preschoolers' physical activity and sedentary behavior. Environment and Behavior, 44(3), 334-349.

Sundhedsstyrelsen. (2016). 60 minutter om dagen ved moderat til høj intensitet. Retrieved from https://sundhedsstyrelsen.dk/da/sundhed-og-livsstil/fysisk-aktivitet/anbefalinger/5-17-aar

Tandon, P. S., Saelens, B. E., \& Christakis, D. A. (2015). Active play opportunities at child care. Pediatrics, 135(6), e1425-31. doi:10.1542/peds.2014-2750 [doi]

Tonge, K. L., Jones, R. A., \& Okely, A. D. (2016). Correlates of children's objectively measured physical activity and sedentary behavior in early childhood education and care services: A systematic review. Preventive Medicine, 89, 129-139. doi:10.1016/j. ypmed.2016.05.019

Tsangaridou, N. (2016). Early childhood teachers' views about teaching physical education: Challenges and recommendations. Physical Education and Sport Pedagogy, , 1-18. doi: 10.1080/17408989.2016.1192593

Tsangaridou, N., Zachopoulou, E., Liukkonen, J., Gråstén, A., \& Kokkonen, M. (2014). Developing preschoolers' social skills through cross-cultural physical education intervention. Early Child Development and Care, 184(11), 1550-1565.

Van Cauwenberghe, E., Labarque, V., Gubbels, J., De Bourdeaudhuij, I., \& Cardon, G. (2012). Preschooler's physical activity levels and associations with lesson context, teacher's behavior, and environment during preschool physical education. Early Childhood Research Quarterly, 27(2), 221-230.

Van Cauwenberghe, E., De Craemer, M., De Decker, E., De Bourdeaudhuij, I., \& Cardon, G. (2013). The impact of a teacher-led structured physical activity session on preschoolers' sedentary and physical activity levels. Journal of Science and Medicine in Sport, 16(5), 422-426. doi:10.1016/j.jsams.2012.11.883

van Zandvoort, M., Tucker, P., Irwin, J. D., \& Burke, S. M. (2010). Physical activity at daycare: Issues, challenges and perspectives. Early Years: An International Journal of Research and Development, 30(2), 175-188.

Wichmann-Hansen, G., Eika, B., \& Mørcke, A. M. (2007). Hvad findes der af litteratur om vejledning? litteratursøgning med fokus på publicerede, evidensbaserede studier. Dansk Pædagogisk Tidsskrift, 3

Williams, C. L., Carter, B. J., Kibbe, D. L., \& Dennison, D. (2009). Increasing physical activity in preschool: A pilot study to evaluate animal trackers. Journal of Nutrition Education and Behavior, 41(1), 47-52.

\section{Fotos:}

fagfotografen.dk for Sport \& Uddannelse Svendborg Kommune 